\title{
A Penhora On-line na Execução Fiscal através do Sistema Bacen Jud e a Proteção ao Siqilo Bancário do Devedor
}

\section{Patrícia Vargas Lopes}

\section{INTRODUÇÃO}

Em 08 de maio de 2001, o Banco Central do Brasil - BACEN, o Conselho da Justiça Federal - ClF e o Superior Tribunal de lustiça firmaram um Convênio de Cooperação técnicoinstitucional prevendo o acesso pelos magistrados, via internet, ao Sistema de Solicitações do Poder Judiciário ao Banco Central do Brasil, denominado BACEN JUD. Mais tarde, idênticos convênios foram celebrados pelo Banco Central do Brasil com o Tribunal Superior do Trabatho e o Superior Tribunal Militar.

Através desse sistema os Tribunais signatários de termo de adesão podem, dentro de suas áreas de competência, encaminhar às instituições financeiras, e demais instituiçōes autorizadas a funcionar pelo Banco Central, determinações de bloqueio e desbloqueio de contas, envolvendo pessoas físicas e jurídicas clientes do Sistema Financeiro Nacional, entre outras funçôes.

Em decorrência da implantação do sistema, firmou-se a possibilidade do juiz efetuar

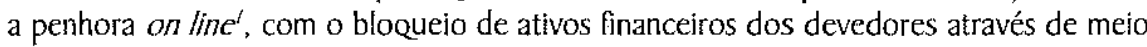
eletrônico, junto àQuelas instituiçōes.

O presente trabalho se propōe a analisar a compatibilidade da penhora on line, através do sistema BACEN JUD, com o direito ao sigilo bancário, prevendo os limites de sua utilização no âmbito da execução fiscal, à luz da legislação aplicável e da jurisprudência pátria.

Para tanto, teceremos breves considerações acerca do direito de sigilo bancário, sua previsão constitucional e infraconstitucional e as principais discussões acerca do tema, Que

\footnotetext{
A expressão on line, importada da língua inglesa, é ordinariamente utilizada para fazer referência a operações comandadas através da rede mundial de computadores (interneth.
} 
assumiu especial relevo a partir da edição da Lei Complementar 105, de 10.01.2001. Prosseguiremos o estudo apresentando o sistema BACEN JUD, tema recentíssimo no cenário jurídico nacional, e, portanto, ainda em fase inicial de abordagem pela doutrina.

A seguir, enfrentaremos a disciplina legislativa do assunto em testilha, buscando responder a Questão central do presente trabalho, Qual seja, se a penhora on line configura violação do direito ao sigilo bancário.

Por fin, daremos conheciniento ao tratamento dispensado à matéria, e sua evolução, pelos tribunais pátrios, especialmente o Tribunal Regional Federal da $4^{2}$ Região e o Tribunal Regional do Trabalho também da $4^{a}$ Região, Que têm ocupado papel de vanguarda na orientação jurisprudencial do país.

\section{O SIGILO BANCÁRIO E O SISTEMA BACEN JUD}

\subsection{0 sigilo bancário no ondenamento jurídico brasileiro}

Embora a Questão envolvendo a proteção do sigilo bancário já tenha sido bastante discutida na doutrina brasileira, cumpre aQui traçarmos algumas breves considerações sobre a matéria, especialmente debatida nos últimos tempos em razão da edição da Lei Complementar $105 / 2001$.

Sigilo bancário é o dever Que têm as instituiçōes financeiras de não revelar informações acerca de operações financeiras e dados bancários relativos a seus clientes a Que tiveram acesso em razão da atividade bancária (natureza obrigacional), bem como o direito dos clientes em ter protegidos pelos bancos seus dados financeiros.

No ordenamento jurídico brasileiro, a origem mais remota acerca do sigilo de informações pessoais nos remete à Constituição de 1824, Que previa em seu art. 179 a inviolabilidade dos direitos civis e políticos dos cidadãos brasileiros, mencionando especificamente o segredo das cartas $^{2}$.

A Constituição Republicana de 1891 e, posteriormente, a Constituição de 1934 mantiveram disposições similares, protegendo a sigilo da correspondência. A Constituição de 1937 continuou assegurando o sigilo das cartas, mas acentuou Que a inviolabilidade poderia ser excepcionada por lei. Da mesma forma o fez a Constituição de 1946. lá na Constituição de 1967, bem como na Emenda Constitucional 01, de 1969, o legislador assegurou o sigilo da correspondência e o sigilo das comunicações telegráficas e telefônicas.

2 Assim dispunha o art. 179 da Constituiçăo de 1824: "A inviolabilidade dos Direitos Civis, e Políticos dos Cidadâos Brazileiros, Que tem por base a liberdade, a segurança individual, e a propriedade, é garantida pela Constituição do Império, pela maneira seguinte: XXVII: O Segredo das Cartas é inviolável. A administração do correjo fica rigorosamente responsável por Qualeuer infraçăo deste Artigo (..). 
Foi na Constituição de 1988, cujo fundamento é o Estado Democrático de Direito e tem como pilar fundamental a dignidade da pessoa humana, Que restou explícita a proteção à intimidade e à vida privada, assim como a inviolabilidade da comunicação de dados e do segredo profissional, diante da consagração dos direitos e garantias individuais.

$\mathrm{O}$ art. $5^{\circ}$, incisos X, XII e XIV, estabelece que:

"Art. $5^{\circ}$ Todos são iguais perante a lei, sem distinção de QualQuer natureza, garantindo-se aos brasileiros e aos estrangeiros residentes no País a inviolabilidade do direito à vida, à liberdade, à segurança e à propriedade, nos termos seguintes: $(. .$.

$\mathrm{X}$ - são invioláveis a intimidade, a vida privada, a honra e a imagem das pessoas, assegurado o direito à indenização pelo dano material ou moral decorrente de sua violação;

(...)

XII - é inviolável o sigilo da correspondência e das comunicações telegráficas, de dados e das comunicaçōes telefônicas, salvo, no último caso, por ordem judicial, nas hipóteses e na forma que a lei estabelecer para fins de investigação criminal ou instrução processual penal;

(...)

XIV - é assegurado a todos o acesso à informação e resguardado o sigilo da fonte, Quando necessário ao exercício profissional.

$(. . .)^{\prime \prime}$

Embora não haja disposição expressa consagrando o sigilo bancário ${ }^{3}$, tanto a doutrina como a jurisprudência afirmam Que na conjugação desses incisos inclui-se o direito de sigilo bancário, erigindo-o a status de direito individual fundamental, seja por um ou por outro fundamento.

A orientação dominante no Supremo Tribunal Federal é no sentido de Que a inviolabilidade da intimidade e da vida privada, previstas no inc. $X$ do art. $5^{\circ}$ da Constituição Federal, são espécies do gênero privacidade, aí incluído o sigilo bancário.

O Pretório Excelso afasta o entendimento de Que o sigilo bancário teria amparo no inc. XII do art. $5^{\circ}$ da Constituição Federal porQue tal dispositivo trata especificamente da violação

\footnotetext{
"Como se pode perceber da leitura ( $^{*}$ do art. $5^{\circ} \mathrm{X}$, XIl e XIV), o texto constitucional contempla os sigilos da correspondência, das comunicações telegráficas, de dados, das comunicações telefônícas e o sigilo profissional, não expondo os sigilos bancário e liscal de maneira expressa, razão pela Qual sua percepção em hierarquia constitucional depende de um esforço interpretativo". TEIXEIRA, Eduardo Didonet: HAEBERLIN Martin. A proteção da Privacidade. Aplicação na Quebra do sigilo bancário e fiscall. Porto Alegre: Sergio Antônio Fabris Ed., 2005, p. 91.
} 
da comunicação de dados, isto é, da interceptação da transmissão de informações por meio eletrônico, independentemente da sua natureza, mas não do registro dos dados $\mathrm{em} \mathrm{si.}^{\ddagger}$ A esse propósito, leciona losé Paulo Baltazar Júnior, em recente obra publicada sobre o tema:

"Afasta-se aqui a tentativa de fundamentar o sigilo financeiro no inciso XII do art. $5^{\circ}$ da Constituição, Que trata das comunicações de dados, e não de dados, Que não estão, por si, cobertos por sigilo, mas encontram-se protegidos eneuanto objeto de correspondência ou de comunicação. Tanto é assim Que se admite a intercepta apenas no caso de comunicação telefônica, em virtude de sua instantaneidade." 5

Há vozes que também entendem que o direito ao sigilo estaria respaldado pela proteção ao sigilo profissional contida no inc. XIV do art. $5^{\circ}$ da Constituição Federal, já Que o dever de guarda de informações financeiras imposto às instituições bancárias é o mesmo Que se impõe a outros profissionais, detentores de informações relacionadas à intimidade do indivíduo, decorrentes da relação de confiança Que se estabelece entre cliente e instituição, tal como entre médicos e pacientes. O ilustre tributarista Hugo de Brito Machado entende Que o sigilo bancário é uma forma de sigilo profissional, sendo este uma garantia de ordem pública, cuja violação está capitulada como crime. ${ }^{6}$

Com essas breves anotações, vê-se Que o direito ao sigilo bancário constitui direito fundamental amparado pelo art. $5^{\circ} \mathrm{da}$ Carta Magna e, por conseguinte, protegido por cláusula pétrea, consoante o disposto no art. $60, \S 4^{\circ}$, da Constituição Federal.

Todavia, mesmo se tratando de direito fundamental, o direito ao sigilo não é um direito absoluto, podendo ser relativizado, desde que respeitados os princípios orientadores da ordem constitucional brasileira. Trata-se, por certo, de direito inabolível, mas que pode sofrer limitações regulamentadas por lei.

Sobre o tema, Alexandre de Moraes no ensina Que:

"os sigilos bancário e fiscal são relativos e apresentam limites, podendo ser devassados pela Justiça Penal ou Civil, pelas Comissões Parlamentares de InQuérito e pelo Ministério Público, uma vez Que a proteção constitucional do sigilo nâo deve servir para detentores de negócios não transparentes ou de devedores que tiram proveito dele para não honrar seus compromissos."

4 Conforme o magistério do Ministro Sepúlveda Pertence, ao apreciar o MS 21.729-4/DF: "(...) Da minha leitura, no inciso Xl! do art. $5^{\circ} \mathrm{da}$ l.ei Fundamental, o que se protege é a comunicação de dados e não os dados, o Que tornaria impossivel Qualquer investigação administrativa, fosse qual fosse.(...)"

5 BALTAZAR IÚNIOR, losé Paulo. Sigilo bancário e privacidade. Porto Alegre: Livraria do Advogado Editora, 2005, p. 62-63.

6 MACHADO, Hugo de Brito. A quebra do sigilo bancário. Repertório $10 B$ de lurisprudência $\pi^{\circ}$ 09/2001. Caderno 1.

7 MORAES, Alexandre de. Direito Constitucional. I 5a ed. São Paulo: Atlas, 2004 
O Supremo Tribunal Federal, guardião maior da Constituição, também em diversas oportunidades já asseverou que o direito ao sigilo bancário não é absoluto, devendo ceder Quando o interesse público se fizer presente. Nesse sentido, manifestou-se nos Recursos Extraordinários no 71 .640-BA e 219.780-PE, cujos acórdãos foram assim ementados:

Sigilo Bancário. As decisões na instância ordinária entenderam que em face do Código Tributário Nacional o segredo bancário não é absoluto. Razoável inteligência do direito positivo federal, não havendo ofensa ao disposto no art. 153 par. 2, da Lei Magna, nem tão pouco negativa de vigência do art. 144 do Código Civil. O objetivo do writ era afastar a exigência de apresentação de fichas contábeis, ao fundamento de violação de sigilo bancário. Inocorrência de dissídio jurisprudencial. Recurso Extraordinário não conhecido.(STF, RE 7| .640-BA, Rel. Min. Djaci Falcão, D| [2/1 1/1971) Constitucional. Sigilo Bancário: Quebra. Administradora de Cartões de Crédito.. CF, art. $5^{\circ}$, X. I. - Se é certo que o sigilo bancário, que é espécie de direito à privacidade, Que a Constituição protege art. $5^{\circ}, X$, não é um direito absoluto, Que deve ceder diante do interesse público, do interesse social e do interesse da Justiça, certo é, também, Que ele há de ceder na forma e com observância de procedimento estabelecido em lei e com respeito ao princípio da razoabilidade. No caso, a Questão foi posta, pela recorrente, sob o ponto de vista puramente constitucional, certo, entretanto, Que a disposição constitucional é garantidora do direito, estando as exceções na norma infraconstizucional. H. - R.E. não conhecido. (STF, RE 21 9.780-PE, Rel. Min. Carlos Velloso, D/ 10/09/1999).

De fato, o direito ao sigilo é passivel de limitações. Segundo Paulo José da Costa Júnior $^{8}$, embora assegurada a proteção à privacidade, as exigências da vida em comum fazem com Que o homem tenha de aceitar restrições na sua esfera privada, seja por imposição do próprio Estado, seja pelas esferas pessoais dos demais indivíduos. Adotando a metáfora utilizada por Eduardo Didonet Teixeira e Martin Haeberlin, o pequeno universo do segredo de Que se reveste a vida privada de cada indivíduo pode ser visto como uma "Fortaleza": "há na fortaleza, uma simples e singela porta, Que pode ser facilmente aberta desde que com a chave certa, pela pessoa certa." 9

A relativização do direito ao sigilo passa ainda pela ponderação de outros princípios insculpidos na Constituição Federal de 1988. São eles os princípios da supremacia do interesse público, da igualdade de tratamento tributário e de justiça social e fiscal.

\& COSTA fúNIOR, Paulo losé da. O direito de estar só: tutela pena da intimidade. São Paulo: Revista dos Tribunais, 1970 apud TEIXEIRA, Eduardo Didonet; HAEBERLIN, Martin. A proteção da Privacidade. Aplicaçăo na Quebra do sigilo bancário e fiscal. Porto Alegre: Sergio Antônio Fabris Ed., 2005

$?$ TEIXEIRA, Eduardo Didonet; HAEBERLIN, Martin, op. cit., p. 95. 
Seguramente, o legítimo interesse público deve prevalecer em relação à proteção da privacidade. Não se trata aqui de simples curiosidade, mas sim de motivo relevante para acesso às informações financeiras reveladoras de rieueza e potencialmente identificadoras de manifestaçöes econômicas tributáveis e de ilícitos penais. Embora o conceito do que se constitui "interesse público" para muitos seja um conceito jurídico de natureza indeterminada, tal não pode ser um obstáculo à sua utilização. Daí a importância de Que os operadores do direito tenham suficiente prudência e razoabilidade para fazer o exame de ponderaçōes de princípios para atingir a melhor e mais adeQuada soluçāo ao caso concreto.

Nesse contexto, não se poderia deixar de invocar o princípio da proporcionalidade como forma de solucionar de modo adequado a colisão de direitos fundamentais que aQui se faz presente. Justifica-se a limitação da privacidade linanceira do indivíduo em face do interesse público Que se verifica na arrecadação de tributos Que revertem para toda sociedade? Entendemos Que sim, mas na exata medida em Que a restrição à privacidade não ultrapasse os limites do razoável e do necessário, o Que deverá ser examinado casuisticamente. Por exemplo, Quando há fortes indícios de que determinado indivíduo esteja praticando crime de sonegação fiscal ou de lavagem de dinheiro, sendo imprescindível a averiguação da sua movimentação financeira, o direito fundamental à privacidade deve ceder em nome do interesse público e da justiça.

Reconhecendo o direito fundamental à vida privada como princípio, e sua possibilidade de relativização, sem que isso afete sua integridade, com suporte no princípio da proporcionalidade na conformação da Constituição, comenta com propriedade losé Paulo Baltazar lúnior Que:

"Seja diante do direito à informação (CRFB, art. $5^{\circ}$, inciso XIV), da moderna criminalidade de colarinho branco, da preservação da moralidade pública (CRFB, art. 37. caput) ou da capacidade contributiva (CRFB, art. $145 \$ 1^{\circ}$ ), há, muitas vezes, necessidade de uma violação ou Quebra do princípio de exclusividade Que informa a proteção da vida privada para assegurar a liberdade de imprensa, a identificação de contribuintes ou fatos geradores e a identificação do fato criminoso e de sua autoria. Em verdade, o crescimento da preocupação com a preservação da vida privada é acompanhado pela pretensão dos poderes públicos e outras forças sociais em conhecer o Que se passa na esfera privada.

Deve ainda ser dito Que a restrição do direito fundamental à vida privada. possivel na medida em Que inexiste direito absoluto se dará, as mais das vezes, em virtude do conflito com interesse coletivo, Que poderá prevalecer em contraponto ao estrito interesse individual. (...) 
Assim é que se impõe, em alguns pontos, fazer uma relativização dessa proteção da vida privada. Essa ponderação não pode ser feita de outra forma Que não seja por meio da aplicação do princípio da proporcionalidade, objeto do item seguinte." 10

Observe «se Que o art. $145, \S 1^{\circ}$, da Constituição Federal, defere à Administração Tributária a faculdade de "identificar, respeitados os direitos individuais e nos termos da lei, o patrimônio, os rendimentos e as atividades econômicas do contribuinte".

Por óbvio Que o respeito aos direitos individuais, aí incluído o sigilo bancário, não pode ser invocado como óbice à essa atribuição constitucional. Fosse assim, então, o dispositivo constitucional seria totalmente esvaziado.

O art. 150, inc. Il, da Carta Magna, também reforça esse entendimento ao estabelecer Que fica vedada a instituição de tratamento desigual entre contribuintes Que se encontrem em situação equivalente. A igualdade tributária somente pode ser tutelada se forem dados ao Fisco instrumentos de fiscalização hábeis à verificação da compatibilidade entre patrimônio (aí incluídas as movimentações financeiras) e rendimentos.

Vistos os fundamentos constitucionais pertinentes à proteção do sigilo bancário, cumpre referìr Que, no âmbito infraconstitucional a matéria vem sendo disciplinada há longa data.

O primeiro instrumento normativo que previu a inviolabilidade dos livros de escrituração mercantil foi o Código Comercial de 1850. Posteriormente, a Lei 4.595/64, em seu art. 38, consagrou o sigilo das operaçóes bancárias e serviços prestados, já prevendo a Quebra excepcional por agentes fiscais, in verbis.

Art. 38 . As instituiçôes financeiras conservarão sigilo em suas operações ativas e passivas e serviços prestados.

(...) $\S 5^{\circ}$ Os agentes fiscais tributários do Ministério da Fazenda e dos Estados somente poderão proceder a exame de documentos, livros e registros de contas de depósitos, Quando houver processo instaurado e os mesmos forem considerados indispensáveis pela autoridade competente."

Embora existissem discussões sobre a amplitude dos termos "processo instaurado" e "autoridade competente", uns entendendo que se trataria de processo administrativo instaurado e autoridade administrativa competente e outros entendendo que se trataria de processo judicial e autoridade judiciária, acabou por prevalecer a última posição na jurisprudência, Que sedimentou entendimento no sentido de Que a Quebra de sigilo bancário somente poderia ser exercida mediante autorização do Poder Judiciário", posição Que prevalece até hoje nos tribunais.

${ }^{10}$ BALtAZAR Júnior, José Paulo, op. cí. p. 45-46.

"Essa foi a linha adotada pelo Superior Tribunal de lustiça, conforme demonstra o seguinte precedente a título ilustrativo: Tribulário. Sigilo Bancário. Quebra com base em procedimento administrativo-fiscal. Impossibilidade. O sigilo bancário do contribuinte não pode ser Quebrado com base $\mathrm{em}$ procedimento administrativo-fiscal, 
Posteriormente, o Código Tributário Nacional também cuidou da matéria no art. 198, assim dispondo, em sua redação original:

Art. 198. Sem prejuízo do disposto na legislação criminal, é vedada a divulgação, para Qualquer fim, por parte da Fazenda Pública ou de seus funcionários, de Qualquer informação, obtida em razão do ofício, sobre a situação econômica ou financeira dos sujeitos passivos ou de terceiros e sobre a natureza e o estado dos seus negócios ou atividades.

Parágrafo único. Excetuam-se do disposto neste artigo, unicamente, os casos previstos no artigo seguinte e os de requisição regular da autoridade judiciária no interesse da justiça.

Adveio, então, a Lei $8.021 / 90$, que em seu art. $8^{\circ}$ trouxe a possibilidade de requisiçăo de informaçōes sobre operações financeiras de contribuintes pela autoridade fiscal, independentemente de autorização judicial. Deve-se aqui registrar que o Plenário do Tribunal Regional Federal da $4^{a}$ Região, ao apreciar a constitucionalidade do art. $8^{\circ}$ da Lei $8.021 / 90$, em face do art. $5^{\circ}$, inc. XII, da Constituição Federal, rejeitou, por maioria de votos, o incidente de Argüição de lnconstitucionalidade na Apelação em Mandado de Segurança n ${ }^{\circ}$ 95.04.44243-9/SC, extraindo-se de sua ementa o seguinte trecho:

" (...) 2. Ainda que se pudesse entender que o art. $8^{\circ}$ da Lei $n^{\circ} 8.021 / 90$ tenha extrapolado o limite estabelecido pela Lei Complementar $n^{\circ} 4.595 /$ 64, o Código Tributário Nacional, em seu art. 196, II, estabelece que os bancos são obrigados a prestar à autoridade administrativa todas as informações de que disponham com relação aos bens, negócios ou atividades de terceiros. Desnecessária, assim, a prévia autorização judicial.

3. As informaçóes sobre o patrimônio das pessoas não se inserem nas hipóteses previstas pelo art. $5^{\circ}$, inciso $X$, da Constituição Federal, porQuanto o patrimônio não se confunde com a intimidade, a vida privada, a honra e a imagem. $(. . .)^{12}$

Com a edição da Lei Complementar 104/2001, foi dada nova redaçăo ao art. 198 do CTN, que passou a ter o seguinte teor:

por implicar indevida intromissão na privacidade do cidadāo, garanța esta expressamente amparada pela Constituiçäo Federal (art. 5, inciso X). Por isso, cumpre as instituiçöes financeiras manter sigilo acerca de QualQuer informaçăo ou documentação pertinente a movimentação ativa e passiva do correntista/contribuinte. bem como dos serviços bancários a ele prestados. Observadas tạis vedaçóes, cabe-thes atender as demais solicitações de informações encaminhadas pelo Fisco, desde Que decorrentes de procedimento fiscal regularmente instaurado e subscritas por autoridade administrativa competente. Apenas o Poder Judiciário, por um de seus órgãos, pode eximir as instituiçốes financeiras do dever de segredo em relação às matérias arroladas em lei. Interpretação integrada e sistemática dos artigos 38, parágrafo 5., da Lei N. 4.595/64 e 197, inciso ll e parágrafo I. do CTN. Recurso improvido, sem discrepância. (RESP 37566 / RS, Rel. Min. Demócrito Reinaldo, 02/02/1994)

12 A íntegra do Incidente de Argüiçăo de Inconstitucionalidade na AMS no 95.04.44243-9 está disponível na Revista do Tribunal Regional Federal da $4^{a}$ Regiăo, $n^{\circ} 29$, Porto Alcgre, 1998, p. 357-371. 
Art. 198. Sem prej̧uízo do disposto na legislação crimina!, é vedada a divulgaçāo, por parte da Fazenda Pública ou de seus servidores, de informação obtida em razão do ofício sobre a situação econômica ou financeira do sujeito passivo ou de terceiros e sobre a natureza e o estado de seus negócios ou atividades.

$\S 1$ o Excetuam-se do disposto neste artigo, além dos casos previstos no art. 199, os seguintes:

1- requisição de autoridade judiciária no interesse da justiça;

II - solicitações de autoridade administrativa no interesse da Administração Pública, desde que seja comprovada a instauração regular de processo administrativo, no órgão ou na entidade respectiva, com o objetivo de investigar o sujeito passivo a que se refere a informação, por prática de infração administrativa.

§ 20 O intercâmbio de informação sigilosa, no âmbito da Administração Pública, será realizado mediante processo regularmente instaurado, e a entrega será feita pessoalmente à autoridade solicitante, mediante recibo, Que formalize a transferência e assegure a preservação do sigilo.

§ 30 Não é vedada a divulgação de informações relativas a:

I - representações fiscais para fins penais;

II - inscriçôes na Dívida Ativa da Fazenda Pública;

III - parcelamento ou moratória.

Sobreveio, por fim, a tão criticada Lei Complementar 105/2001, Que passou a disciplinar o sigilo das operações financeiras, dando azo à interposição de ações diretas de declaração de inconstitucionalidade ${ }^{13}$, ainda não examinadas pelo Supremo Tribunal Federal.

As críticas dirigem-se especialmente à disposição contida no art. $6^{\circ 14}$, Que prevê o acesso pelas autoridades administrativas às contas de depósitos bancários e aplicações financeiras, independentemente de autorização do Poder Judiciário. Afirma-se que a Lei Complementar 105/200 I afronta o princípio da separação dos poderes, bem como o princípio da reserva da jurisdição, afastando o Poder Judiciário de função Que the é constitucionalmente outorgada e legitimando o princípio da autotutela. Haveria comprometimento na imparcialidade, pois a Administração pauta-se pela discricionariedade.

13 Săo ełas as ADINs 2386, 2397, 2390, 2406 e 2389, todas apensadas. O Procurador-Geral da República já ofereceu parecer, manifestando-se, no mérito, pela constitucionalidade dos arts. $3^{\circ}, \S^{\circ}, 5^{\circ}$ e $6^{\circ}$ da LC 105/2001; do art. $1^{\circ}$, na parte Que altera o art. 98 da Lei $5.172 / 66$ e the acrescenta o inciso Il e o $\$ 2^{\circ}$, da LC 104/2001; do $\$ 2^{\circ}$ do art. 11 da Lei $9.311 / 96$; e do art. $1^{\circ}$ da Lei $10.172 / 2001$, na parte que introduz o $\$ 3^{\circ}$ ao art. 1 i da lei $9.311 / 96$.

14 Art. $6^{\circ}$ da Lei Complementar 105/2001: Art. $6^{\circ}$ As autoridades e os agentes fiscais tributários da União, dos Estados, do Distrito Federal e dos Municíplos somente poderăo examinar documentos, livros e registros de instituições Anancciras, inclusive os referentes a contas de depósitos e aplicações financeiras, Quando houver processo administrativo instaurado ou procedimento fiscal em curso e tais exames sejam considerados indispensáveis pela autoridade administrativa competente. Parágrafo único. O resultado dos exames, as informações e os documentos a Que se refere este artigo serăo conservados em sigilo, observada a legislaçăo tributária. 
Os argumentos em contrário residem em defender Que a Lei Complementar 105/ 2001 assim como seu decreto regulamentador, Decreto 3.724/200 I, passam pelo exame de constitucionalidade porque preservam a intimidade e a privacidade do indivíduo fiscalizado, restringindo as hipóteses legais de quebra de sigilo e a competência para fazê-lo, além de submeter os agentes públicos a controle administrativo e responsabilidade penal, civil e administrativa. Ao submeter a norma ao exame de ponderação de princípios, argumenta-se Que os princípios da preservação da privacidade devem ceder frente ao princípio da igualdade no tratamento tributário e ao ideal de justiça social e fiscal. Afirma-se, ainda, Que a lei não prevê exatamente a Quebra do sigilo bancário, mas sim a sua conversão em sigilo fiscal, já Que as informações permanecem de caráter sigiloso para o Fisco, ficando a Administração como verdadeira depositária fiel dos dados. Dando suporte a tais afirmações, invoca-se o direito comparado, asseverando-se que a tendência mundial é a flexibilização do sigilo bancário frente ao Fisco. À exceção dos países denominados paraísos fiscais, inúmeros Estados têm legislação Que dá acesso automático à movimentação financeira dos correntistas à Fiscalização Tributária. É o caso da Espanha, da França, da Bélgica, da Inglaterra, da Hungria e da Turquia. ${ }^{15}$

Defende-se, ainda, Que a Quebra do sigilo bancário pela Administração é viável em razão dos princípios de presunção de legitimidade e da auto-executoriedade dos atos de polícia administrativa. Considera-se que todos esses atos estão suleitos a controle jurisdicional em caso de lesão ou ameaça a direito, bem como na hipótese de abuso de autoridade, mas que tal controle deve ser a posteriori, através dos instrumentos constitucionais próprios, preservando-se a função típica do Poder Judiciário, Que é a função jurisdicional.

Defendendo a constitucionalidade da LC 105/200!, José Paulo Baltazar Júnior conclui Que:

"Em suma, nossa posição é pela inocorrência de inconstitucionalidade na autorização dada pela $L C n^{\circ}$ 105/01, de acesso direto a informações financeiras por parte de autoridades administrativas fazendárias, independentemente de autorização judicial, desde Que obedecidos os parâmetros estabelecidos pela própria Lei Complementar e pelas normas regulamentadoras. Não havendo, no caso, reserva de jurisdição, nem vislumbrando violação dos princípios do devido processo legal e da proporcionalidade, os dispositivos da LC ora comentados não padecem de vício de inconstitucionalidade. ${ }^{\text {"16 }}$

Tais são, em linhas gerais, o arcabouço legislativo apresentado de forma cronológica e as principais discussões Que envolvem a proteção ao sigilo bancário no Brasil. Resta-nos saber se essa disciplina conflita com a penhora on line via sistema BACEN JUD, Que a seguir apresentaremos.

15 Para detalhes sobre o sigllo bancário no direito comparado, verificar estudo claborado por FOLMANN, Melissa. Interpretação constitucional principiológica \& sigilo bancário. $4^{\text {a }}$ edição. $3^{\mathrm{a}}$ tiragern. Curitiba: Juruá Editora, 2004, p. 89 e seguintes.

${ }^{16}$ BALTAZAR IÚNIOR, losé Paulo. op. cit. p. 162. 


\subsection{A penkora on line através do sistema BaCEN JUD: características e fundamento legal}

A penhora é, antes de tudo, ato executivo Que afeta bens do devedor aptos a satisfazer o direito de crédito do credor. A definição clássica de penhora de Liebman é a seguinte:

"A penhora é o ato pelo Qual o órgão judiciário submete a seu poder imediato determinados bens do executado, fixando sobre eles a destinação de servirem à satisfação do direito do exeQüente" 17 .

Para Araken de Assis, a penhora se define por ato executivo dotado de eficácia satisfativa, Que afeta determinado bem à execução, permitindo sua ultertor expropriação, $\mathrm{e}$ tornando os atos de disposição de seu proprietário ineficazes em face do processo. ${ }^{18}$

Tais definições aplicam-se tanto à penhora no âmbito da execução civil como no âmbito da execução fiscal. Aliás, convém lembrar Que a própria lei de execução fiscal, Lei 6.830 , de 22 de setembro de 1980, dispõe Que a execução judicial da dívida ativa da União, dos Estados, do Distrito Federal, dos Municípios e de suas respectivas autarquias será regida subsidiariamente pelo Código de Processo Civil.

Pois bem. O artigo 591 do Código de Processo Civil assenta expressamente a responsabilidade patrimonial do devedor ao dispor que "o devedor responde. para o cumprimento de suas obrigações, com todos os seus bens presentes e futuros, salvo as restriçōes estabelecidas em lei."

lá o artigo 655 do CPC dispõe Que incumbe ao devedor, observar a seguinte ordem ao proceder à nomeação de bens à penhora:

Art. 655. Incumbe ao devedor, ao fazer a nomeação de bens, observar a seguinte ordem:

1 - dinheiro;

II - pedras e metais preciosos;

III - títulos da dívida pública da União ou dos Estados:

IV - títulos de crédito, Que tenham cotação em bolsa;

$V$-móveis;

$\mathrm{Vl}$-veículos;

Vll-semoventes;

VIII - imóveis

IX - navios e aeronaves;

$X$ - direitos e açóes.

" LIEBMAN, Enrico Tulio. Processo de Execução, São Paulo: 1946 apud BAPTISTA DA SiLVA, Ovídio. Curso de Processo Civil. Vol. Il. Porto Alegre: Sergio Antonio Fabris Editor, 1990.

18 ASSIS, Araken de. Manual do Processo de Execução. $5^{a}$ edição. Săo Paulo: Editora Revistas dos Tribunais, 1998 
Na mesma linha, a Lei de Execuções Fiscais, em seu artigo I 1, possui disposição semelhante.

Tanto no Código de Processo Civil Quanto na Lei de Execuções Fiscais, observa-se Que o dinheiro figura em primeiro lugar na ordem de bens sujeita à penhora. Aliás, em recente acórdão emanado do Tribunal Regional do Trabalho da $4^{a}$ Região, nos autos do mandado de segurança n ${ }^{\circ} 01$ 882-2004-000-04-00-0, publicado em 13/10/2004 e cuja relatoria coube a luíza Cleusa Regina Halfen, colhemos, a esse respeito a seguinte argumentação:

(...) Ressalta-se, por oportuno, Que a penhora de dinheiro é a forma menos onerosa de execuçâa, tanto que é este bem o primeiro na ordem de preferência, estabelecida no art. 655 do CPC, de observância impositiva em relação ao devedor, tanto Que o art. 656, do mesmo diploma, preconiza que a nomeação será ineficaz, "salvo convindo o credor". Logo, somente o credor poderá preterir a ordem legal estabelecida. Como bem preleciona Manoel Carlos Toledo Filho, "É intuitivo que a penhora em dinheiro será quase sempre, para o devedor, de imediato, mais onerosa. Dinheiro pode transformar-se em bens; já a reciproca não é necessariamente verdadeira. Logo, levando-se ao extremo a regra prevista pelo artigo em comento, não se penhoraria dinheiro de ninguém, transformando-se em letra morta o inc. I do art. 655 do CPC" (in Penhora em Dinheiro - Artigo 620 do CPC Mandado de Segurança, Revista Síntese Trabalhista, $n^{\circ} 131$, maio de 2000 , p.06). (...)

Importante frisar, ainda, Que, no âmbito da execução fiscal, a penhora pode ocorrer mediante nomeação espontânea de bens pelo devedor (art. $9^{\circ}$, inc. III, da Lei 6.830/80), obedecida a ordem legal, ou mediante coerção, via oficial de justiça (art. 10 da mesma lei), em que poderá recair sobre QualQuer bem do executado, ressalvados os absolutamente impenhoráveis.

A penhora de coerção é a mais comum e se dá através de oficial de justiça, mediante indicação de bens pelo credor, em face da inércia do executado em oferecer bens à penhora. Ou seja, em Que pese se tratar de penhora forçada, não há surpresa para o devedor, Que já fora citado anteriormente e já tivera oportunidade para oferecer bens em penhora, tudo nos termos dos artigos 652 e seguintes do CPC e artigo $7^{\circ}$ da Lei $6.830 / 80$.

Não rarás vezes, no entanto, o prosseguimento da execução esbarra na impossibilidade de localizar bens disponíveis à penhora, seja porque já se esgotaram os meios ordinários de localização de bens (diligências no DETRAN, Registro de Imóveis, etc), sę̣a porque o devedor propositalmente tenta ocultar seu patrimônio.

Nesse contexto, e diante da evolução tecnológica operada nos últimos anos, construiuse o que se denomina hoje a penhora on line, como forma de agilizar o processo executivo e dar--the maior efetividade. 
A penhora on /ine foi concebida através do sistema BACEN JUD, com a celebração de um convênio de cooperação técnico-institucional entre o Banco Central do Brasil, o Superior Tribunal de Justiça e o Consetho de Justiça Federal, firmado em 08 de maio de $200 \mathrm{l}$, bem como entre o Banco Central do Brasil e o Tribunal Superior do Trabalho, firmado em 05 de março de 2002, prevendo o acesso pelos magistrados, via internet, ao Sistema de Solicitações do Poder ludiciário ao Banco Central do Brasil, mediante senha pessoal criptografada e intransferível, os Quais poderão solicitar informações sobre a existência de contas correntes e aplicações financeiras, assim como determinar o bloqueio ou desbloqueio de contas e comunicar a decretação e extinçâo de falências, relacionadas a pessoas físicas e jurídicas clientes do Sistema Financeiro Nacional. objeto:

Consta do parágrafo único, cláusula primeira, do aludido convênio, relativo ao seu

Cláusula Primeira - (..)

Parágrafo único - Por intermédio do sistema BACEN JUD, o ST], o CIF e os Tribunais signatários de Termo de Adesão, poderão, dentro de suas áreas de competência, encaminhar às instituiçōes financeiras e demais instituições autorizadas a funcionar pelo BACEN, solicitações de informações sobre a existência de contas correntes e aplicações financeiras, determinações de bloqueio e desbloqueio de contas e comunicações de decretação e extinção de falências envolvendo pessoas físicas e jurídicas clientes do Sistema Financeiro Nacional, bem como outras solicitações eue vierem a ser definidas pelas partes."

Tal prática veio agilizar a prestação de informações diariamente solicitadas às instituiçôes financeiras através de oficios do Poder Judiciário, bem como as ordens de bloqueio e desbloqueio de contas.

Conforme informação obtida no sítio oficial do Banco Central do Brasil (unww.bcb.gov.br). o BACEN recebe em média seiscentas solicitações diárias de informações enviadas por papel, o Que gera volume considerável de trabalho de triagem, classificação e reenvio dos pedidos à rede bancária, e cerca de duas mil ordens diárias via eletrônica. Com o sistema BACEN IUD é o próprio juiz Que preenche um documento eletrônico na internet, transmitindo com segurança os dados diretamente aos bancos, Que cumprem as ordens e retornam as informações solicitadas com maior racionalidade, agilidade e economia.

O sistema vem, na realidade, atender a anseio dos credores, sejam eles públicos ou privados, e do próprio Poder Judiciário, Que recebia inúmeros pedidos de ofícios do Fisco, conforme comenta o luiz Federal Heraldo Garcia Vitta na obra Execução Fiscal doutrina e jurisprudência, ao abordar a expedição de ofícios ao Banco Central, de onde transcrevemos o seguinte excerto:

O que nos figura inconveniente é o pedido, feito pelo credor, para Que o juízo oficie ao Banco Central do Brasil, visando à localìzação de conta bancária do devedor. A diligência é dispendiosa e de difícil cumprimento. Abarrota os 
Cartórios com a expedição de oficios de longa tramitação e não se coaduna com o "interesse público" Que deve haver para a diligência determinada pelo Judiciário. Excepcionalmente, a expedição de oficio à Receita Federal ou à determinada instituição bancária tem reflexos positivos, em especial nos casas em Que os responsáveis tributários (art. 135 do CTN) escondem seus bens. ${ }^{19}$

A utilização do sistema, no entanto, ainda é restrita, mas vem aumentando dia após dia. Segundo informações divulgadas pelo Banco Central em seu sítio oficial, no ano de 2004 foram emitidas, via BACEN IUD, 467 mil ordens judiciais, sendo Que $94 \%$ delas oriundas da Justiça do Trabalho, e o restante dividido entre a Justiça Federal ( $2 \%$ ) e a Justiça Comum ( $4 \%$ ). Em papel, no ano de 2004 foram aproximadamente 1 1 6.000 ordens judiciais, sendo 28.174 oriundas da Justiça do Trabaiho, 86.920 emanadas da Justiça Comum e apenas 1000 vindas da Justiça Federal. Tais números nos evidenciam Que as Jusțiças Federal e Comum ainda estão recalcitrantes ao uso do sistema BACEN JUD, mas isso não Quer dizer Que tais justiças não façam uso do serviço, só Que ainda de forma manual, através da sistemática de envio de ofícios.

Esse receio no uso do sistema reflete-se nas decisões judiciais, conforme demonstraremos no capítulo final desse trabalho.

É necessário frisar que a Lei 6.830 , de 22 de setembro de 1980 , estabeleceu o rito procedimental da execução fiscal, bem como normas de direito material. Díta lei retratou as necessidades daquela época, mas não acompanhou a evolução tecnológica operada nos últimos anos.

Assim, embora alì não haja previsão legal específica tratando da penhora eletrônica, verifica-se Que a Lei $6.830 / 80$ também não impõe óbice nenhum a Que a penhora se efetive desse modo. Enquanto antigamente o juízo emitia ofício determinando o bloqueio de determinada Quantia depositada em estabelecimento bancário, agora o sistema BACEN IUD permite Que a operação se dê de modo instantâneo. A penhora do dinheiro é a mesma prevista no art. I I, inc. I, da Lei de Execuçôes Fiscais, houve apenas a mudança do modus operandi, com considerável ganho de tempo.

Saliente-se que o anteprojeto da nova Lei de Execuções Fiscais está na pauta de discussōes do Congresso Nacional e foi recentemente submetido à consulta pública, nele já estando prevista a possibilidade de prática e comunicação de atos processuais por meio eletrônico, dando aos tribunais a competência para disciplinar a matéria ${ }^{20 .}$

A tendência é, portanto, no sentido de agilizar os atos processuais através de recursos de informática, Que se tornam muito menos onerosos para o Estado e trazem consigo a possibilidade efetiva de satisfação do crédito.

\footnotetext{
19 ALVARES, Manoel et at. Execução Fiscal, Doutrina e Jurisprudência. Coordenação Vladimir Passos de Freitas. São Paulo: Saraiva, 1998, p. 242-243.

${ }^{20}$ Segundo ant. 16 do Anteprojeto de Lei de Cobrança da Dívida Ativa: Art 16 Os tribunais, no âmbito da respectiva jurisciçãa, poderão disciplinar a prática e a comunicação dos atos processuais por meios cletrônicos.
} 
Recentemente, com a publicação da Lei Complementar 118, de 09/02/2005, Que instituiu o art. I 85-A ao CTN, com vigência a partir de 09/06/2005, pode-se afirmar que a penhora on line através do BACEN IUD ganhou suporte legal. O dispositivo legal é ineQuivoco ao determinar ao juiz a decretação de indisponibilidade de bens e direitos, comunicando às autoridades supervisoras do mercado bancário, preferencialmente por meio eletrônico, quando o devedor tributário citado, não efetuar o pagamento nem nomear bens à penhora no prazo legal. Vejamos o novo texto do art. I 85-A do CTN, acrescido pelo art. $2^{\circ}$ da LC I 18/2005:

"Art. 185-A. Na hipótese de o devedor tributário, devidamente citado, não pagar nem apresentar bens à penhora no prazo legal e não forem encontrados bens penhoráveis, o juiz determinará a indisponibilidade de seus bens e direitos, comunicando a decisão, preferencialmente por meio eletrônico, aos órgãos e entidades Que promovem registros de transferência de bens, especialmente ao registro público de imóveis e às autoridades supervisoras do mercado bancário e do mercado de capitais, a fim de Que, no âmbito de suas atribuições, façam cumprir a ordem judicial.

$\S I^{9} \mathrm{~A}$ indisponibilidade de Que trata o caput deste artigo limitar-se-á ao valor total exigível, devendo o juiz determinar o imediato levantamento da indisponibilidade dos bens ou valores que excederem esse limite.

$\$ 2^{\circ}$ Os órgãos e entidades aos Quais se fizer a comunicação de Que trata o caput deste artigo enviarão imediatamente ao juízo a relação discriminada dos bens e direitos cuja indisponibilidade houverem promovido."

A partir da vigência do art. 185 -A do CTN, não se poderá mais recusar a aplicação da penhora on line com fundamento na inadeQuação do instrumento - convênio - como veículo dessa sistemática, o Que é invocado por alguns operadores do direito como empecitho à sua adoção, já Que existirá norma geral de direito tributário regulando a Questão.

Acrescente-se, por oportuno, Que nem toda aplicação financeira é passivel de penhora. Há Que se preservar as verbas de natureza alimentar, tais como salários, proventos de aposentadoria e pensões. Não se incluem na restrição à penhora os valores depositados em poupança ou em aplicaçōes financeiras, ainda Que tenham origem nos salários recebidos, perdendo tal natureza porque sobejaram, mês-a-mês, o necessário à subsistência familiar. ${ }^{21}$

${ }^{21}$ Nesse sentido fol proferido acórdão pelo Tribunal Regional do Trabalho da $4^{\text {a }}$ Região, assim ementado: MANDADO DE SEGURANÇA. BLOQUEIO DE NUMERÁRIO EM CONTA BANCÁRJA. Em princípio, inexiste ilegalidade ou abuso de poder na ordem de bloquelo, ou penhora, de numerário. Aplicação da Orientaçâo Jurisprudencial $n^{\circ} 60$ da SDI-2 DO c. TST. Todavia, dada sua natureza alimentar, os salários, săo absolutamente impenhoráveis, "salvo para pagamento de prestaçăo alimentícia", nos termos do art. 649, inciso IV, do CPC. Constatando-se que os salários do impetrante, servidor público, são depositados na conta corrente na eulal procedeu-se ao blopuejo de numerário, tern-se por impenhorável o valor procedente do depósito do salário pago ao impetrante no mês de abril/2004. Já os valores aplicados em fundos de investimentos ou poupança, mesmo Que tenham origem nos salários recebidos, perdem tal natureza, pois Que sobejaram, mês a mês, o necessário à subsistência familliar. Segurança concedida, em parte, confirmando a liminar deferida. (MS 0|882-2004-000-04-00-0, Rel. Juiza CLEUSA REGINA HALFEN D| 13/10/2004). 
Note-se que o usuário (juiz) emite ordem de bloqueio do valor necessário à garantia da dívida, sendo eue sua incidência ocorrerá somente sobre o saldo livre e disponível no dia da efetivação do bloqueio, sem considerar Quaisquer limites de crédito (cheque especial ou crédito rotativo, por exemplo).

Convém ainda salientar que a penhora on line não conflita com o princípio da menor onerosidade da execução para o devedor, enunciado no art. 620, caput, do CPC, assim redigido:

Art. 620. Quando por váríos meios o credor puder promover a execução, o juiz mandará Que se faça pelo modo menos gravoso para o devedor.

Segundo tal princípio, a utilização do meio mais gravoso só é possivel Quando, tentados todos os meios menos gravosos, ainda assim tiver restado frustrada a execução.

A adoção do sistema BACEN IUD se conforma a esse princípio, tendo em vista Que não está sendo reeuerida pelo credor de modo indiscriminado, embora não haja óbice formal, pois o dinheiro está estampado como bem preferencial na ordem legal, mas tão-somente nas hipóteses de esgotamento dos meios ordinários de localização de bens ou de ausência total de bens aptos à penhora. Ademais, se é verdade eue a execução deve se dar do modo menos gravoso para o devedor, não menos verdade é oue a execução deve se dar no interesse do credor, segundo princípio estampado no artigo 612 do CPC. Conforme textualmente previsto no código processual, a execução por Quantia certa tem por objeto expropriar bens do devedor, a fim de satisfazer o direito do credor (art. 646), possuidor de título executivo. Ressalte-se, mais uma vez, Que o devedor não é surpreendido pela penhora on line uma vez Que já tomou ciência da execução e já teve oportunidade de nomear bens à penhora. Se não o fez, fica sujeito à constrição forçada seguindo a ordem legal.

É notória a dificuldade, tanto do Fisco Quanto do próprio Oficial de Justiça, longa manus do luiz, em localizar bens visíveis no patrimônio do executado, hábeis à constrição; daí porque a penhora on line surge como efetivo meio de satisfação do crédito.

Feitas essas considerações, não poderíamos deixar de mencionar Que o sistema BACEN JUD vem sendo alvo de críticas contumazes de diversos operadores do direito em razão de algumas falhas operacionais, como bloqueio total da conta do correntista ${ }^{22}$. De fato, o sistema possui algumas falhas, muitas delas geradas por má utilização e falta de conhecimento para sua operação, o Que não pode ser visto como obstáculo intransponível à sua adoção. Muitos juízes vinham determinando o bloqueio total da conta, ao invés de efetuar a opção de bloqueio de valor determinado, resultando em constrição em excesso.

\footnotetext{
${ }^{22}$ Ainda assim, o sistema conta com o apoto do Conselho Federal da Ordem dos Advogados do Brasil, conforme nota conjunta firmada juntamente com o TST, de 26/05/2004, Que transcrevemos parcialmente: "O sistema que se convencionou chamar "penhora on-line" decorre de um convênio que o ludiciário firmou com o Banco Central do Brasil, ao qual aderiu o Tribunal Superior do Trabalho, em idêntico procedimento ao que já praticava a lustiça Comum de alguns estados e, em especial, a Justiça Federal nas execuçóes fiscais. O objetivo dessa adesẫo era o de dar cumprimento ao art. 114 da Constituição da República, o Qual confere
} 
Em razão disso, o Banco Central efetuou uma série de ajustes no ano de 2004, passando o sistema a alertar que as ordens judiciais de bloqueio total visam a atender apenas as decretações de indisponibilidade total de bens. Também foram introduzidos esclarecimentos Quanto ao alcance exato da ordem judicial para evitar dúvidas e interpretações equivocadas sobre o valor a ser atingido (saldo credor livre e disponivel na data da efetivação do bloQueio) e informação sobre ausência de remuneração da conta ${ }^{23}$.

Atualmente, já está em fase de implantação a primeira etapa da versão 2.0 do BACEN JUD, Que prevê a solicitação e resposta de bloquelo, desbloqueio e transferência de valores para contas judiciais, tudo de modo eletrônico, permitindo Que haja a correção imediata e on line de eventual excesso de penhora, bem como o controle de respostas dos bancos pelo Juízo solicitante.

competência à lustiça do Trabalho para julgar os dissídios entre trabathadores e empregadores. $O$ ato de "julgar" não se restringe a declarar o direito, mas se estende a realizá-lo, efetivando-o.

Por tal razäo, após decidir, incumbe à Justiça trabalhista, até de ofício (CLT, art. 878), cumprir e fazer cumprir suas decisões, cujo implemento é um dever do Estado e um direito dos cidadãos. Somente então se realiza, em sua plenitude, a prestaçấo jurisdicional. O sistema, portanto, insere-se no campo dos deveres do Estado para com a sociedade. Nada além disso. Mesmo assim, sáo observadas todas as garantias próprias do devedor, Que pode discutir os cálculos que the são apresentados. Antes disso, todos os recursos podern ser oferecidos, assegurados a ampla defesa e o contraditório. Não pagando, a lei faculta ao devedor garantir o processo "mediante o depósito" da Quantia, de modo espontâneo, livre, sem quaisquer ingerências do Judiciário (CLT, art. 882). Há, inclusive, a possibilidade de conciliação, mesmo após a decisão judicial. Apenas na ausência dessas iniciativas e caso não se encontre dinheiro é que se pode avançar para outros bens, na ordem estabelecida em lei (CPC, art. 655). O mesmo se dá na execuçöes fiscais (Lei de Execuçăo Fisscal $n$ 6.830, de 22/09/1980, art. 11). O Poder (udiciário somente se envolve na omissão do devedor e, como não poderia ser diferente, observa a ordem seuüencial de bens penhoráveis. O sistema faz exatamente isso: consulta a existência de dinheiro; se houver, apenas bloqueia a Quantia, informando ao juiz para que, Querendo, proceda a penhora pela forma prevista em lei. Assim, o meio é extremamente seguro para todos: devedor, credor e para o Estado, Que pode, linalmente, cumprir sua missão constitucional. Ademais, a penhora en dinheiro, com uso da informática, fica menos onerosa ao Estado, pela desburocratização dos atos processuais, como, sobretudo, para o devedor, Que, na hípótese de penhora sobre bens, terá outros encargos iguaimente onerosos, como o custo do registro da penhora, de publicação de editais e da praça para venda, por exemplo. Com tal sistema, a Justiça do Trabatho atende aos reclamos de toda a sociedade, ainda que essa velocidade seja contrária ao interesse de uma minoria. O que há de mais grave é que o projeto discrimina o credor trabalhista, pois o sisterna Bacen-jud continuará a ser processado por outras justiças, vale dizer, em favor do credor tributário, do credor banqueiro, etc. O projeto parte da falsa premissa de que a fustiça do Trabalho é a única a se valer do sisterna do Banco. Central. A advocacia tem manifestado expressa concordância com o método empregado, Quer por sua licitude, quer por sua racionalidade. O ludiciário deve mesmo ser dotado de meios tecnologicamente mais avançados para assegurar a efetividade e autoridade de suas decisões, para que possa gozar da confiança dos cidadäos.

Natural que, por se tratar de um novo sistema, deve, como qualquer outro, merecer constante aperfeiçoamento. Condenável não é a sua adoçăo, mas a tentativa de, sȩ̣a por meio de Ação Declaratória de Inconstitucionalidade (ADIn 3091), seja por proposta legislativa (PL 2597/2003), obstar a efetivação de um sistcma Que nada mais é senão levar a modernidade, com legalidade, para garantia da respeitabilidade, às instituiçôes judiciais.

${ }^{23}$ A esse respeito, justifica o Banco Central que: "As contas correntes não são passiveis de remuneração pelas regras do Sistema Financeiro Nacional; apenas as contas de depósitos judiciais são passiveis de remuncração c a transferência de valores para esses depósitos depende de ordem judicial específica, opçăo atualmente nắo disponivel no Bacen Jud; a instituição financelra que transferir valores bloqueados sem ordem judicial 
Deve-se registrar que o Tribunal Superior do Trabalho está à frente na implantação do sistema BACEN JUD, não só pelo elevado número de acessos, como também pelo manifesto incentivo aos magistrados para Que adotem prioritariamente o sistema. A Corregedoria-Geral da Justiça do Trabalho expediu o Provimento 01/2003, publicado no Diário de Justiça de 1\%07/2003, no Qual expressamente consigna, no art. $1^{\circ}$, Que, se tratando de execução definitiva, o sistema BACEN IUD deve ser utilizado com prioridade sobre outras modalidades de constrição judicial.

Além disso, em setembro de 2003, aquela Corte Superior criou um cadastro permitindo às empresas indicarem a conta bancária para ser feito o bloqueio da dívida, com vistas a evitar a retenção de valores em mais de uma conta. A iniciativa já conta com 611 empresas cadastradas.

Expostas, ainda que de forma sucinta, a proteção ao sigilo bancário prevista na ordem jurídica brasileira, assim como a penhora on line e seu funcionamento através do sistema BACEN IUD, cumpre-nos agora enfrentar o cerne desse trabalho: averiguar se a penhora on line configura Quebra de sigilo bancário.

\section{A PENHORA ON LINE ATRAVÉS DO SISTEMA BACEN JUD CONFICURA VIOLAÇÃO AO DIREITO DE SIGILO BANCÁRIO?}

\subsection{Há quebra de siqilo bancário?}

Tanto na doutrina Quanto na jurisprudência há vozes dissonantes. Enquanto uns defendem a penhora on line como instrumento eficaz de satisfação de crédito do credor e realização de justiça, diga-se de passagem não somente no âmbito da execução fiscal, outros recusam sua aplicação por entenderem Que há afronta ao direito de sigilo consagrado na Constituição Federal de 1988.

A penhora on line, como anteriormente já exposto, nada mais é do Que a efetivação da constrição patrimonial em dinheiro através do bloqueio eletrônico de saldo em aplicaçōes financeiras eventualmente existentes em nome do executado, tão-somente em Quantia suficiente para garantir a dívida exeQüenda, e sem acesso à movimentação financeira, saldo ou origem dos valores depositados.

especifica arcará com os tributos decorrentes dessa operação (CPMF, IOF), pois não terá suporte legal para repassá-fos a ciente numa eventual ordem de desbloqueio. A nova versão do sistema, porém, já viabilizará a transferência dos valores bloQueadas para conta judicial, hipótese que tornará possível a remuneração." conforme nota explicativa às alterações implementadas a partir de 19.08.2004 constante no sítio oficial dapuela autarquia.

${ }^{24}$ Conforme manual de introdução ao sistema BACEN JUD constante do sítio oficial do Banco Central do Brasil (www.bcb.gov.br) acessado em 02/03/2005: "O sistema BACEN /UD impacta, de alguma forma, a Quebra de sigilo bancário das pessoas físicas e jurídicas ? Não. lá é permitido aos juizes, por força de lei, determinar a bloqueio de ativos financeiros e obter de entidades públicas ou privadas 
Segundo informações oficiais constantes do sítio do Banco Central, o sistema BACEN JUD não configura Quebra de sigilo fiscal ${ }^{24}$. Concordamos com esse entendimento. Ao discorrermos acerca da penhora on line no capítulo anterior, vimos que se trata de procedimento não vedado por lei e que em breve terá disciplina própria com a vigência do art. 185-A do CTN. Vimos, ainda, Que ordens de bloqueio de contas sempre foram emitidas pelo Poder ludiciário, através de ofícios dirigidos aos bancos, sem que se cogitasse de violação ao direito de sigilo bancário.

A penhora on line através do BACEN JUD não disponibiliza ao exeoüente qualquer informação acerca da vida financeira do devedor. Há simplesmente a emissão de ordem, por autoridade judiciária, para que seja efetuado o bloquelo de Quantia certa, tornando o numerário afetado ao processo de execução como qualquer outra penhora. Se não houver saldo suficiente para garantia total da execução, a ordem de bloqueio recai sobre o valor total existente na conta, mas não há, em nenhum momento, a divulgação dos lançamentos, débitos ou depósitos do titular da conta.

A penhora de Quantia certa não pode ser considerada como devassa na vida privada do devedor porQue efetivamente não invade a seara de sua intimidade ou de sua privacidade.

Há que se considerar, ainda, que os dados prestados através do sistema BACEN IUD pelas instituições financeiras são disponibilizados ao juiz e não ao exeqüente, a Quem cumpre apenas solicitar a penhora do valor correspondente ao da execução fiscal no caso da eventual existência de contas ativas. Nesse sentido, a penhora on line revela-se até mesmo instrumento de maior proteção à intimidade do executado, pois, tratando-se de penhora realizada em papel, o fato é que os ofícios expedidos pela rede bancária são juntados aos autos, com a divulgação dos dados para o credor e serventuários da justiça, bem como a Qualquer indivíduo que tenha em mãos o processo.

É necessário que se diga Que o sistema BACEN JUD não criou nenhuma regra processual ou material nova, trata-se apenas de nova sistemática de penhora, Que obedece fielmente a ordem legal de bens sujeitos à constrição judicial.

as informaçôes necessárias para instruçăo de processos, respeitadas as regras constitucionais e processuais vigentes. Na verdade, os juizes poderiam enviar suas determinações diretamente às instituições linanceiras, todavia, pela facilidade de comunicação com o Sistema Financeiro que dispöe o Banco Central, e no contexto de uma política de aproximação e cooperação com o Judiciário, este Órgão, desde os anos 80 vem auxiliando na intermediação desse processo. Nesse período, o volume de solicitaçốes judiciais cresceu substancialmente: hoje recebe-se una média de 600 solicitaçôes diárias, encaminhadas em papel, suscitando enorme trabalho de triagem, classificação, digitação e reenvio das solicitaçōes à toda rede bancária. No novo sistema Bacen Jud, não haverá a necessidade do envio do documento em papel nem do envolvimento do Bacen no processo. $\mathrm{O}$ próprio juiz preenche um documento eletrônico na Internet, Que contém todas as informaçöes hoje inscritas no ofício comum. Como vem ocorrendo nos últimos 20 anos, esses dados são transmitidos, com segurança, diretamente aos bancos Que cumprem as ordens e retornam as informaçóes aos juizes. Ou seja, o sistema apenas permite Que um oficio Que era encaminhado em papel seja agora encaminhado via internet, racionalizando os serviços no âmbito do Banco Central e possibilitando ao Poder judiciário mais agilidade no cumprimento de suas ordens no âmbito do Sistema Financeiro Nacional." 
Ademais, a utilização do BACEN JUD atende aos preceitos legais estabelecidos em torno do sigilo bancário, atualmente previsto na Lei Complementar 105/0 I. Observe-se Que $o$ artigo $1^{\circ}, \S 3^{\circ}$, inc. $\mathrm{Vl}$, da aludida lei complementar, dispóe expressamente Que:

Art. $1^{\mathbb{A}}$ As instituições financeiras conservarão sigilo em suas operações ativas e passivas e serviços prestados.

(...)

$\S 3^{2}$ Não constitui violação do dever de sigilo:

(...)

VI - a prestação de informações nos termos e condições estabelecidos nos artigos $2^{\circ}, 3^{\circ}, 4^{\circ}, 5^{\circ}, 6^{\circ}, 7^{\circ}$ e 9 desta Lei Complementar.

Mais adiante, $\mathrm{o}$ artigo $3^{\circ} \mathrm{da}$ mesma lei estabelece que:

Art. 3ํ Serão prestadas pelo Banco Central do Brasil, pela Comissão de Valores Mobiliários e pelas instituições financeiras as informações ordenadas pelo Poder Judiciário, preservado o seu caráter sigiloso mediante acesso restrito às partes, Que delas não poderão servir-se para fins estranhos à lide.

Tais disposições legais evidenciam Que não há Quebra de sigilo bancário Quando a prestação de informaçôes é ordenada por um dos órgãos do Poder Judiciário, desde Que preservado o seu caráter sigiloso. Além disso, verifica-se Que a própria Lei Complementar 105/2001 prevê penalidade rigorosa no âmbito criminal (art. 10) ao agente público Que fizer uso indevido das informações, sem prejuizo da responsabilidade civil objetiva da entidade pública (art. 11).

O Código Tributário Nacional, por sua vez, prevê expressamente a requisição de informações, feita pela autoridade judiciária, Quando houver o interesse da justiça (art. 198. $\S I^{\circ}$, inc. I), vedada a sua divulgação.

Nessa hipótese, parece evidente Que o interesse da justiça é a prestação jurisdicional ${ }^{25}$, cujo efeito imediato é a satisfação do crédito tributário aposto na certidão de dívida ativa, e mediato, a reversão desse crédito em prol de toda a sociedade, através da prestação de serviços públicos.

${ }^{25}$ Neste sentido, a jurisprudência pátria de longa data tem se manifestado, conforme corroboram os seguintes acótdãos: EXECUÇÃO. BENS DO DEVEDOR. INFORMAÇÖES. BANCO CENTRAL. I - En face do interesse da justiça na efetivaçăo da penhora e restando comprovado Que foram esgotados os demais meios à disposição da credora, admitir-se-á a requisição de informaçốes ao Banco Central pelo Juízo sobre a existência de contas bancárias do devedor. 2 - Precedentes. 3 - Recurso provido. (ST). Resp 144823 / PR, rel. Min. losé Delgado, Df 17.11.1997) - RECURSO ESPECIAL. PEDIDO DE INFORMAÇŌES A ÓRGÃOS PÚBLICOS POSS!BILIDADE. I. O pedido de informações a órgãos públicos (Receita Federal, Banco Central, etc) visando localizar bens susceptíveis de penhora, em processo de execução, é feito, segundo entendimento pretoriano, no "interesse da justiça como instrumento necessário para o Estado cumprir o seu dever de prestar jurisdição." 2. As informaçóes, no entanto, guardam caráter sigiloso e serăo de uso restrito, com resguardo da privacidade do devedor. 3. Recurso especial não conhecido. (ST], Resp 489378 / SP, Rel. Min. Fernando Gonçalves, DI 25.08.2003). PROCESSO CIVIL. EXECUÇÄO FISCAL. PENHORA. REQUISIÇÃO DE INFORMAÇÖES À RECEITA FEDERAL. POSSIBILIDADE. 1 . Esgotados 
Não é demasiado referir que o Convênio firmado pelo Banco Central do Brasil, o Conselho da Justiça Federal, o Superior Tribunal de lustiça prevê cláusula expressa no sentido da manutenção do sigilo de toda e Qualeuer informação obtida ${ }^{26}$.

Dessa feita, não são aplicáveis ao sistema BACEN IUD as críticas que se fazem ao artigo $6^{\circ}$ da LC 105/2001, Que prevê acesso aos dados dos correntistas independentemente de autorização do Poder Judiciário, pois aqui o exeqüente dirige seu pedido ao juiz e este maneja diretamente o sistema. Portanto, preservado o princípio da reserva de jurisdição.

Tampouco há de se falar em afronta ao princípio do devido processo legal e ao princípio do contraditório porque o pedido de bloqueio é solicitado pelo Fisco somente após a citação do executado e o decurso de prazo para que nomeie bens à penhora, sendo cumpridas fielmente as disposições processuais e resguardando-se o direito à oposição de embargos após a garantia da dívida.

O BACEN JUD, por não disponibilizar ao Fisco dados financeiros dos executados, não constitui instrumento de intervenção arbitrária estatal para colher informações sobre a vida privada dos executados. Conforme já ressaltado anteriormente, a penhora atinge o valor certo da execução relativa ao processo, não implicando em bloqueto total das contas e tampouco em busca de informaçōes sobre origem, natureza e destino dos valores depositados. A utilizzação é tão-somente destinada à garantia do crédito tributário. Nada mais.

Há que se ter presente que o convênio que instituiu a penhora on line foi firmado pelo Conselho de Justiça Federal, órgão colegiado composto de Ministros do Superior Tribunal de Justiça e por Desembargadores Federais dos Tribunais Regionais Federais do País, a Quem compete determinar as providências necessárias ao regular funcionamento da Justiça e à disciplina forense, sendo presumível Que tenha se orientado em respeito aos preceitos constitucionais e legais. Conclusão diversa implicaria em concluir Que o aludido convênio, firmado por intérpretes abalizados da lei, teria estipulado autorização abstrata de Quebra de sigilo bancário, violando direito fundamental. Não é esse o caso, pois como já vimos a sistemática de bloqueio de contas por intermédio do Banco Central já é de longa data utilizada pelo Poder Judiciário.

os meios para localização dos bens do executado, é admissivel a requisição, através do juiz da execução, de informaçóes à Receita Federal, face ao interesse da justiça na realização da penhora.2. Recurso especial conhecido e provido. (STI, Resp 161.296/RS, Rel Min. Francisco Peçanha Martins, Dj 08.05.2000. AGRAVO DE INSTRUMENTO. EXECUÇÃO FISCAL. REQUISIÇÃO DE INFORMAÇÕES À RECEITA FEDERAL. POSSIBILIDADE. Frustrados os esforços do credor para localizar bens do devedor, para garantir a execução; é possivel a Quebra do sigilo bancário e fiscal, sendo admissivel a reQuisição de informaçöes junto à Receita Federal. Neste caso, a requisiçăo é feita no interesse da Justiça, como instrumento necessário para o Estado cumprir o seu dever de prestar jurisdição. Precedentes do ST). Agravo provido. Voto vencido. (T)/RS AGRAVO DE INSTRLIMENTO No 70006478333, Rel. Des. Francisco /osé Moesch. /. 19/11/2003)

26 "Cláusula Décima Primeira - Além das responsabilidades previstas neste instrumento, os partícipes se obrigam a: a) manter sigilo acerca dos sistemas de segurança utilizados, bem como das informaçöes de cue os envolvidos na execução deste Convênio tiverem conhecimento: (...)" Disposição idêntica consta da claúsula Décima Segunda do Convênio firmado entre o Banco Central e o Tribunal Superior do Trabaiho. 
Embora o aludido convênio tenha sido submetido a controle de constitucionalidade concentrado, através do ajuizamento da Ação Direta de Inconstitucionalidade no 3091 -4/ DF, até a presente data pendente de decisão pelo Supremo Tribunal Federal, há que se presumir que os atos administrativos, aí incluídos os convênios, foram expedidos em conformidade com a lei.

A referida ADIN no 309 -4/DF ajuizada pelo Partido da Frente Liberal - PFL invoca Que o convênio celebrado entre Banco Central e o Tribunal Superior do Trabalho, assim como os Provimentos $0 \mathrm{l}$ e 03 da Corregedoria-Geral da Justiça do Trabalho têm caráter normativo, prestando-se, por isso, ao controle abstrato de constitucionalidade. Aduz, em síntese, Que tais instrumentos estão violando o art. $1^{\circ}$, caput, incisos II, III e IV, da Constituição Federal, além de afrontar direitos e garantias fundamentais, constantes do art. $5^{\circ} \mathrm{da}$ Carta, entre eles o direito à intimidade e à vida privada e o sigilo de dados.

O Procurador-Geral da República já ofereceu o parecer $\mathrm{n}^{\circ} 2.444 / \mathrm{CF}^{27}$, manifestandose pela constitucionalidade do convênio, bem como dos provimentos que dispuseram sobre a matéria. Em primeiro lugar, reconhece Que os atos impugnados não podem figurar como objeto de ação direta de inconstitucionalidade, pois se tratam de atos estatais concretos, despojados de normatividade ou de generalidade. Afirma que os juizes sempre se comunicaram com o Banco Central para obter informações sobre contas bancárias para instrução dos processos de execução judicial, o Que antes era feito mediante ofício, e com o sistema BACEN JUD passou a ser feito por meio eletrônico. Assevera Que não há Qualeuer inovação na ordem jurídica, sequer criação de norma processual, tratando-se apenas de facilitar a penhora de dinheiro. Refere Que há previsão constitucional para celebração de convênios, Que permitem a gestão associada de serviços públicos (art. $241 \mathrm{da} \mathrm{CF}$ ). Refuta a tese de oue haveria violação à garantia do sigilo bancário, repetindo as palavras do E. Presidente do Tribunal Superior do Trabalho em suas informações, as Quais permitimo-nos transcrever:

"em momento algum o juiz da causa toma conhecimento do teor dos depósitos bancários do devedor. O software, uma vez acionado, limita-se a verificar se, em alguma entidade financeira do país, há conta bancária em nome do executado, e se, em tal conta, uma vez existente, há importância suliciente para satisfazer a ordem judicial. Não dá a ele informaçōes sobre outros valores, ou valores excedentes porventura existentes na mesma conta. Limitase a responder ao juiz da causa que bloqueou a importância requisitada, Que, depois, será transferida à agência do Banco do Brasil ou da Caixa Econômica Federal, à disposição do juiz requisitante."

27 Parecer $n^{\circ}$ 2.444/CF , exarado em 23/04/2004 pelo Procurador-Geral da República, Exmo. Sr. Cláudio Fonteles, acostado às fls. $185-193$ dos autos da Ação Direta de inconstitucionalidade $n^{\circ} 3.091$-4/DF, 
Acrescenta, ainda, Que:

" De toda a forma, não se pode esquecer pue as informações são solicitadas pelo juiz da execução, não se podendo falar, portanto, em violação ao devido processo legal, à ampla defesa e ao contraditório, assim como alegar violação ao sigilo bancário."

Outro aspecto relevante a salientar é o de Que somente faz sentido falar-se em proteção à privacidade e do sigilo como direito individual amparado pela Constituição Federal relativamente às pessoas naturais, e não às pessoas jurídicas. É certo Que as empresas podem ter segredos industriais, em relação aos Quais não há o menor interesse em conhecimento pelo Estado, mas a sua vida financeira afeta a administração tributária e por isso não se justifica que tais dados sejam inacessíveis, muito menos através de requisição emanada do Poder Judiciário, como é o caso da aplicação do BACEN IUD. A esse propósito, o magistério do Ministro Francisco Rezek é bastante elucidativo, no voto proferido no julgamento do Mandado de Segurança $n^{\circ} 21.729 \sim 4 / D F$, em Que se discutia a transferência do sigilo bancário para o Ministério Público, ao discorrer sobre o art. $5^{\circ}$, inc. X, da Constituição:

"O inciso $\mathrm{X}$ do rol de direitos fala assim numa intimidade onde a meu ver seria extraordinário agasalhar a contabilidade, mesmo das pessoas naturais, e por melhor razão a das empresas.

Numa reflexão extra legal, observo Que a vida financeira das empresas e das pessoas naturais não teria mesmo poreue enclausurar-se ao conhecimento da autoridade legítima - não a justiça tão-só, mas também o parlamento, o Ministério Público, a administração executiva, já que esta úitima reclama, pela voz da autoridade fiscal, o inteiro conhecimento do patrimônio. dos rendimentos, dos créditos e débitos, até mesmo do mais discreto dos contribuintes assalariados. Não seì a Que espécie de interesse serviria a mística do sigilo bancário, a menos que se presumam falsos os dados em registro numa dessas duas órbitas, ou em ambas, e por isso não coincidentes o cadastro fiscal e o cadastro bancário das pessoas e empresas. ${ }^{28}$

De QualQuer forma, ainda Que se pudesse cogitar de Quebra de sigilo bancário, na adoção da penhora on line, há argumento de autoridade Que resguarda expressamente essa possibilidade em ações cíveis, inclusive para fins de localizar bens penhoráveis, com amparo em precedentes do Tribunal Regional Federal da $4^{a}$ Região:

“De nossa parte, como já afirmamos no item 2.4.7.5., a LC n 105/2001, embora não tenha regulamentado expressamente, tampouco vedou a Quebra de sigilo em ações cíveis. É Que a Quebra de sigilo pela autoridade judicial

${ }^{28}$ Acórdăo citado por SARAIVA FILHO, Oswaldo Othon de Pontes, no artigo "O acesso diłeto aos dados bancários por parte do Fisco: a transferência do sigilo bancário para o sigilo fiscal". Revista Fórum de Direito Tributário. Belo Horizonte, ano 2, n.11, p.63-109, set/out.2004. 
está regulamentada, de forma genérica, no art. $3^{\circ}$, sem Que tenha esgotado a enumeração das hipóteses. Como lá afirmado, seria contraditório entender Que poderá a autoridade fazendária Quebrar o sigilo, sem autorização judicial, para possibilitar o lançamento tributário, mas que idêntica medida estaria vedada à autoridade judicial em uma demanda na Qual se pretende obter justamente a execução forçada daQuela obrigação tributária ou, com maior razão, de obrigação alimentar. Demais disso, também a eficácia e a concretização da prestação jurisdicional dão suporte à medida. Assim, entendemos admissivel a Quebra de sigilo em ações cíveis, a fim de localizar bens executáveis, desde que demonstrados os esforços do exeqüente no esgotamento de outros meios ( TRF4a R., Al n ${ }^{\circ}$ 2002.04.01.007358-6/ PR, Rel. Des. Fed. Maria Lúcia Luz Leiria, J ${ }^{a}$ T., D 7.8 .02 , p. 3 I 1, TRF4 R., Al n 2001.04.01.089465-6/SC, Rel. Dês. Fed. Luiz Carlos de Castro Lugon, I ${ }^{\mathrm{a}} \mathrm{T}$., un., D| 30.10 .02 , p.852) ou "em presença de indícios de ilicitude e de fraude objețivando a ocultação de bens" (TRF 4a R., Al 2003.04.01.0523640/SC, Rel. Des. Fed. Luiz Carlos de Castro Lugon, $3^{\mathrm{a} T}$., un., (1 1.5 .04$)^{\prime 29}$

Por fim, importa ressalvar, Que mesmo que se admitisse Que há quebra de sigilo bancário, a Lei Complementar 105/200I é inequívoca ao resguardar as informações obtidas pela Administração, transformando o sigilo bancário em sigilo fiscal. Mais do Que isso, prevê penalidade para quem fizer uso indevido das mesmas, pois "o que a lei autoriza é identificar, e não dar publicidade aos fatos"30.

Ora, se a própria Lei Complementar confere à atividade de fiscalização o acesso às informações bancárias nos termos ait estabelecidos, com major razão ainda deve ser privilegiada a penhora on line, em que há o controle judicial efetivo da medida.

A penhora on line atende ao interesse do credor, possuidor de título executivo dotado de liquidez e certeza, bem como ao interesse da justiça, pois o sucesso da execução é instrumento fundamental para Que o Poder Judiciário se desincumba de seu dever de prestar jurisdição.

\subsection{Panorama Jurisprudencial}

A jurisprudência sobre a matéria encontra-se ainda incipiente, sendo raros os precedentes que analisam a Questão especificamente Quanto à aplicabilidade do BACEN JUD, especialmente nos Tribunais Superiores.

\footnotetext{
29 BALTAZAR IÚNIOR, Iosé Paulo. op. cit. p. 132-133.

30 Idem. P 159.
} 
O Convênio celebrando pelo BACEN e pelo Tribunal Superior do Trabatho está sendo objeto da ADIN no 309 1-4/DF, conforme já referido, mas até o presente momento não hạ manifestação do Supremo Tribunal Federal sobre a matéria.

No âmbito da Justiça Federal do Rio Grande do Sul, o aludido convênio foi objeto da Açăo Declaratória $n^{\circ}$ 2002.71.00.009947-9, sendo proferida sentença pelo Juiz Federal Leandro Paulsen, em setembro de 2004, e cujo trecho a seguir transcrevemos:

Vejamos os vícios atribuídos ao Convênio na inicial, fl. 04 dos autos: 'O Convênio possui um sem número de vícios, Que podem ser assim resumidos: a) ele não prevê a forma, o modo, o momento processual ou as condiçóes para a utilização deste poderoso instrumento; b) ele não prevê a necessidade de intimação da parte 'investigada' da Quebra de seu sigilo bancário, Que é feita 'por oficio eletrônico' (leia-se e-maili), sem deixar rastros no processo; c) ele não respeita, portanto, os princípios do contraditório, da ampla defesa e do devido processo legal; d) ele não impóe respeito aos requisitos elencados no CPC, na parte em que trata do arresto, para a realização do tal "bloquelo eletrônico'; e) ele não impốe respeito aos requisitos do CPC na parte em Que outorga AO DEVEDOR a prerrogativa de primeiro indicar bens à penhora; f) ele não impõe respeito aos mandamentos do CPC na parte em Que exige Que a execução se faça pelo menos meio gravoso ao devedor; g) ele não subordina a Quebra do sigilo bancário à prática de qualquer ilegalidade, ou à presença dos requisitos elencados na $\mathrm{LC} \mathrm{n}^{\circ} \mid \mathbf{0 5}$; h) ao autorizar o ingresso nas contas e o bloqueio de valores através de 'ofício eletrônico', ele permite o exercício da jurisdição FORA DOS AUTOS DO PROCESSO, o que impossibilita Qualquer tipo de controle por parte do administrado, e possibilita o desvirtuamento do poder jurisdicional em autoritarismo. O Convênio BACEN/ TRT é omisso em todos este aspectos.' Tenho que do próprio elenco de vícios já se pode perceber Que, em verdade, o Convênio em Questão não regula as matérias ali tratadas. Aliás, o próprio Autor reconhece Que o convênio é omisso quanto aos requisitos e condições para a quebra do sigilo. Eé assim é porque não se tem, no referido Convênio, que implanta o chamado sistema BACEN JUD, Qualquer inovação legislativa quanto ao sigilo bancário. o Qual, por certo, encontra-se regrado pela $\mathrm{LC} \mathrm{n}^{\circ} 105 / 01$. Deve o mesmo ser visto de modo contextualizado, à luz das normas materiais e processuais vigentes. O sistema em Questão, conforme se infere da documentação acostada aos autos, simplesmente prevê a utilização de meio eletrônico para o encaminhamento de ofícios 'contendo solicitações de informações sobre a existência de contas correntes e aplicações financeiras, determinações de bloqueio e desbloqueio de contas envolvendo pessoas físicas e jurídicas clientes do Sistema Financeiro Nacional, bem como outras solicitações'. Não implica, o sistema, QualQuer supressão de prerrogativas processuais do devedor, ampliação das hipóteses ensejadoras da Quebra de sigilo bancário 
ou mesmo atenuação de recuisitos para tanto. Cuida da veiculação de decisóes judiciais para a identificação de ativos financeiros e respectivo bloqueio, decisões estas que pressupõem, elas próprias, a análise dos pressupostos para tanto pelo Magistrado e eue são de cumprimento obrigatório pelos destinatários da ordem. A omissão do Convênio quanto aos inúmeros pontos destacados na inicial, antes de constituírem um vício, revelam a ausência de QualQuer interferência nas nomas materiais e processuais pertinentes, não dispensando os Magistrados da sua observância, até porQue não poderia fazêlo. [...] De fato, não se pode vislumbrar na transmissão eletrônica de ofícios judiciais e das respectivas respostas, em si e por si, a violação de direitos fundamentais. A insurgência contra o Convênio implica combate ao instrumento de comunicaçâo, Quando, em verdade, a violação ou não ao sigilio deste nunca decorrerá, mas, eventualmente, da decisão Quanto à Quebra do sigilo em tais ou Quais circunstâncias em contraste com a legislação aplicável ${ }^{3 !}$.

No Superior Tribunal de Justiça, se encontram decisōes entendendo gue a requisição judicial é medida excepcional, Que somente se verifica Quando houver barreira intransponível na obtenção dos dados, comprovada pela demonstração ineQuívoca das diligências levadas a cabo pelo exeqüente, e Quando for de relevância para a prestação jurisdicional ${ }^{32}$.

Há ainda julgados Que abordam a reeuisiçăo de informaçōes à Secretaria da Receita Federal cuando frustrados os meios de localização de bens, concluindo por sua admissibilidade no interesse da justiça, interpretação essa Que se conforma à hipótese da penhora on line. A título ilustrativo, transcrevemos o julgado abaixo, proferido pela Corte Especial do Superior Tribunal de Justiça em sede de Embargos de Divergência em Recurso Especial:

\section{EXECUÇÃO. REQUISIÇÃO DE INFORMAÇÕES À RECEITA FEDERAL, A PEDIDO DO EXEQÜENTE, QUANDO FRUSTRADOS OS ESFORÇOS PARA LOCALIZAR BENS DO EXECUTADO. ADMISSIBILIDADE. ART. 600, CPC.}

A reQuisição, frustrados os esforços do exeQüente para localização de bens do devedor para a constrição, é feita no interesse da justiça como instrumento necessário para o Estado cumprir o seu dever de prestar jurisdição. Não é somente no interesse do credor.

Embargos conhecidos e acolhidos (ST], EResp 163.408/RS, rel. Min. José Arnaldo da Fonseca, D| (1/06/2001)

31 PAULSEN, Leandro. Direito Tributário. Constituiçăo e Código Tributário à Luz da Doutrina e da jurisprudência. $7^{3}$ ediçäo. Porto Alegre: Livraria do Advogado, 2005, p. $\{307$.

32 Nesse sentido, as decisōes proferidas pelo Min. losé Delgado no Resp 641.826 - SC, DI 18/08/2004; e no Resp 644.456 - SC, DI 05/08/2004, Que negaram seguimento aos recursos especiais da Fazenda Nacional e do INSS, respectivamente. Na mesna linha , o Resp no 703.882 que negou seguimento ao recurso especial da Fazenda Nacional por se tratar de matéria de índole constitucional. 
Quanto à adoção do BACEN JUD, a Primeira Turma do Superior Tribunal de Justiça acaba de proferir o primeiro julgado sobre a matéria, sinalizando seu entendimento nessa mesma linha, todavia não de forma unânime:

\section{EXECUÇÃO FISCAL. LOCALIZAÇÃO DE BENS. QUEBRA DE SIGILO} BANCÁRIO. EXPEDIÇÃO DE OFÍCIO AO BACEN.

1. Não é cabível a Quebra de sigilo fiscal ou bancário do executado para Que a Fazenda Pública obtenha informações acerca da existência de bens do devedor inadimplente, excepcionado-se tal entendimento somente nas hipóteses de estarem esgotadas todas as tentativas de obtenção dos dados pela via extrajudicial. Precedentes.

2. No caso concreto, o acórdão reconheceu a impossibilidade de obtenção dos dados pela vía extrajudicial.

3. Agravo regimental provido. (STl, Ag.RG no REsp nº 644.456-SC, Rel. Min. Teori Albino Zavascki, vencido Min. José Delgado, Que havia negado seguimento ao recurso especial, DI 04/04/2005)

Em seu voto, o Min. Teori Albino Zavascki reconhece a possibilidade de adoção do sistema BACEN JUD na hipótese em Que restarem esgotadas as tentativas do Fisco na obtenção dos dados, in verbis.

“ (...) 2. É importante salientar, inicialmente, Que o convênio celebrado, em 08.05.200 I, entre o Banco Central do Brasil, o Superior Tribunal de Justiça e o Conselho da Justiça Federal objetivou apenas facilitar o encaminhamento pelas autoridades judiciárias, por intermédio de sistema informatizado (BACEN JUD), "às instituições financeiras e demais instituições autorizadas a funcionar pelo BACEN", de "solicitações de informaçōes sobre a existência de contas correntes e aplicações financeiras, determinaçôes de bloqueio e desbloqueio de contas e comunicações de decretação e extinção de falências envolvendo pessoas físicas e jurídicas clientes do Sistema Financeiro Nacional, bem como outras solicitaçôes Que vierem a ser definidas pelas partes" (cláusula primeira, parágrafo único). Cuida-se, portanto, de acordo de cooperação técnica, com o Qual se pretendeu otimizar a operacionalização das medidas acima mencionadas, e Que, evidentemente, não tem o condão de ampliar as hipóteses legalmente admitidas de adoção dessas providências.

3. Conforme demonstrado nos julgados colacionados no voto do relator, a jurisprudência do ST) está sedimentada no sentido de Que não é cabivel a Quebra de sigilo fiscal ou bancário do executado para Que a Fazenda Pública obtenha informações acerca da existência de bens do devedor inadimplente. excepcionando-se tal entendimento somente na hipótese de estarem esgotadas todas as tentativas de obtenção dos dados pela via extrajudicial. No caso em exame, o TRF reconheceu que "tem razão o INSS ao referii a impossibilidade de comprovar o esgotamento de todos os meios para descobrir bens penhoráveis da empresa devedora. Conforme se vê do final do despacho 
agravado, o MM. Juiz Federal determinou a suspensão da execução com base no art. 40 da Lei $6.830 / 80$. Isso, por si só, demonstra Que não foram encontrados bens penhoráveis. Ademais, a certidão de fls. $53 / 54$ também atesta tal impossibilidade" (fl. 60). Tem-se, assim, por satisfeito o requisito do esgotamento dos meios extraįudiciais de obtenção dos dados.(.)"

No Tribunal Regional Federal da $4^{\mathrm{a}}$ Região, a primeira decisão sobre a matéria rechaçou frontalmente a adoção do sistema BACEN JUD, tendo o Eminente Desembargador Federal Relator, Dr. Fábio Rosa, entendido Que haveria violação ao sigilo bancário. A decisão restou assim ementada:

AGRAVO DE INSTRUMENTO.INDEFERIMENTO DE PEDIDO DE RETENÇÃO DE VALORES PORVENTURA EXISTENTES EM CONTA DOS EXECUTADOS UTILIZANDO-SE DO SISTEMA BACEN IUD. SIGILO BANCÁRIO. QUEBRA.

I. A LC 105/200! estabelece no art. $1^{\circ}$ Que as instituiçōes financeiras conservarão sigilo em suas operações ativas e passivas e serviços prestados. $\mathrm{O}$ art. $2^{\circ}$ da lei reza: o dever de sigilo é extensivo ao Banco Central do Brasil, em relação às operações que realizar e às informações que obtiver no exercício de suas atribuições.

2. Estaria a exclusiva informação sobre existência de contas correntes excluída do âmbito do direito à intimidade? A LC 105 esclarece Que não. Basta interpretar-se o $\S 1^{\circ}$ do art. $2^{\circ}$, onde dispöe-se Que o sigilo, inclusive Quanto a contas de depósitos, aplicações e investimentos mantidos em instituições financeiras, não pode ser oposto ao Banco Central do Brasil. Disso deflui a conclusão evidente no sentido de que a existência de contas de depósitos e aplicações financeiras ficam resguardados pelo sigilo, só não oponível ao BACEN. 3. Observe-se que o convênio firmado entre o BACEN e o CIF (BACEN JUD) apenas visa a facilitar o acesso aos dados, Quando a Quebra do sigilo é autorizada, sendo Que as hipóteses estão taxativamente disciplinadas na LC 105 (art. $1^{\circ}, \S 4^{\circ}$, art. $3^{\circ} \mathrm{e}$ art. $6^{\circ}$ ). Descobrir bens penhoráveis não constitui motivo para autorizar a Quebra do sigito bancário. Essa foi opção política do legislador ao formular a regra.

4. Dessa maneira, não se haverá de lançar mão do convênio BACEN JUD, ignorando-se os limites impostos pela LC 105, o que até pode tipificar o crime do art. 10 da lei em Questăo.

5. Enquanto não houver lei Que tutele o erário previdenciário, expondo a vida econômica dos devedores, pela relativização de seu direito à intimidade, não se pode Quebrar sigilo bancário por sistema algum. É ilícito administrativo e penal. 6. Agravo de instrumento improvido e agravo regimental prejudicado. (TRF4aR, Al no 2003.04.01.03225 I-7/SC, Rel. Des. Federal Fábio Rosa)

Tal entendimento, contudo, foi superado com a superveniência de novas decisões aceitando a aplicação do BACEN JUD para localização de numerário a ser penhorado, desde 
Que o exeqüente comprovasse já ter esgotado as possibilidades de localização de patrimônio do devedor. Nesse sentido, os seguintes acórdãos:

\section{EXECUÇÃO FISCAL. LOCALIZAÇÃO DE CONTAS BANCÁRIAS} ATRAVÉS DO SISTEMA BACEN IUD. MEDIDA EXCEPCIONAL.

Em caráter excepcional, Quando não localizados outros bens passiveis de constrição, é viável, em execução fiscal, a localização de contas em nome do executado mediante utilização do sistema BACEN JUD. (TRF4ª, Al no 2003.04.01.044849-5/SC, Rel. Des. Federal Dirceu de Almeida Soares, D) $07 / 01 / 2004$ )

AGRAVO DE INSTRUMENTO. BACEN IUD. CONTA CORRENTE. BLOQUEIO DE VALORES. PENSÃO. BENS IMPENHORÁVEIS,

1. É pacífica a jurisprudência dos tribunais no sentido de que o sistema do BACEN JUD deve ser utilizado em situações excepcionais, de modo a tutelar a garantia constitucional do sigilo bancário.

2. Ao meu ver, deve ser utilizado o sistema do BACEN-jUD quando o exeQüente efetivamente tomou providências concretas visando à localização de bens penhoráveis, tais como pesquisas junto aos departamentos de trânsito e cartórios de registros de imóveis, medidas essas adotadas no caso em tela.

3. Não obstante a decisão agravada tenha ressalvado a impossibilidade de recair a constrição sobre bens impenhoráveis, faz-se mister ratificar tal determinação, uma vez Que a pensão percebida pela parte agravante é depositada na conta bancária bloqueada.

4. Agravo de instrumento parcialmente provido. (TRF4ar, Al $n^{\circ}$ 2004.04.01 .0 13350-6, Rel. Des. Federal Álvaro Junqueira, D| 18/08/2004) AGRAVO DE INSTRUMENTO. EXECUÇÃO DE SENTENÇA. LOCALIZAÇÃO DE BENS PENHORÁVEIS. QUEBRA DO SIGILO BANCÁRIO. MEDIDA EXCEPCIONAL.

1. Pacificou-se a jurisprudência dos tribunais no sentido de Que a utilização da base de dados do Banco Central - seja através dos antigos oficios encaminhados manualmente às instituições bancárias, seja através do BACENJUD - deve ser utilizado em situações excepcionais, de modo a tutelar a garantia constitucional do sigilo bancário.

2. O sistema do BACEN-JUD deve ser utilizado Quando a exeqüente efetivamente tomou providências concretas visando à localização de bens penhoráveis, tais como pesquisas junto aos departamentos de trânsito e cartórios de registros de imóveis.

3. Agravo de Instrumento improvido. (TRF4aR, AI n 2004040 I008987-

6, rel. Juiz convocado Ricardo Teixeira do Valle Pereira, DI 07/07/2004)

Mais recentemente foi exarado o seguinte acórdão, em Que resta ineQuivoca a posição do juízo de que o sistema BACEN IUD não importa em quebra de sigilo bancário:

TRIBUTÁRIO. AGRAVO DE INSTRUMENTO. EXECUÇÃO FISCAL. 
SISTEMA BACENIUD. LOCALIZAÇÃO DE BENS PASSÍVEIS DE PENHORA.

A utilização do sistema BACEN JUD para a identificação de conta corrente e/ou aplicações financeiras de titularidade do devedor, com o fim de obter informações sobre bens passíveis de penhora, deve ser utilizado somente em casos excepcionais e mediante a comprovação de que o exeqüente esgotou os meios de que dispõe para localizar o patrimônio do executado. (TRF4aR, Al 2004.04.01.048161-2/RS, rel. Des. Fed. João Surreaux Chagas, DI [6.03.2005)

No voto condutor do acórdão, o Relator assevera Que:

"(...) Inicialmente, convém referir Que a existência do convênio Bacen Jud não altera em nada os requisitos para a obtenção de informações junto ao Banco Central. O convênio, Que está restrito aos Tribunais, diz apenas coma operacionalização da reQuisição de informações, diminuindo a burocracia Quando o pedido é deferido pelo juízo.

A jurisprudência pátria admite de forma restrita a expedição de ofícios pelo juízo a órgãos da administração pública para fins de obtenção de informações necessárias à localização de bens passíveis de garantir o juízo, ainda Que isso possa acarretar Quebra do sigilo bancário ou fiscal. Para que seja deferida a expedição, contudo, deve o exeQüente comprovar Que exauriu os meios à sua disposição para localizar o patrimônio do executado.

Nesse sentido, transcrevo precedentes do Colendo Superior Tribunal de Justiça:

Execução Fiscal. Ofício à Receita Federal. Requerimento de informações sobre bens do devedor passíveis de penhora.

1. Fincou a Corte orientação no sentido de Que o deferimento de expedição de oficio a órgãos da administração pública, com o fim de obter informações sobre bens passiveis de penhora, é restrito aos casos excepcionais e após a comprovação de que o exeqüente exauriu os meios à sua disposição para localizar o patrimônio do executado, requisito não demonstrado no caso concreto.

2. Precedentes jurisprudenciais. Incidência da Súmula $83 / S T$ ].

3. Recurso nâ o conhecido. (Primeira Turma, RESP /60238/RS, Rel. Min. Milton Luiz Pereira, D/U, 25/06/2001, p. (06)

RECURSO ESPECIAL " ART. 105, III, "a", CF “ AJUIZAMENTO CONTRA ACÓRDÃO PROFERIDO EM AGRAVO DE INSTRUMENTO " EXECUÇÃO FISCAL MOVIDA CONTRA CONTRIBUINTE QUE ENCERROU IRREGULARMENTE SUAS ATIVIDADES “ NÃO LOCALIZAÇÃO DO ENDEREÇO E DE BENS DA EXECUTADA " CITAÇÃO DOS SÓCIOS " PRETENDIDA EXPEDIÇÃO DE OFÍCIO À RECEITA FEDERAL PARA OBTENÇÃO DE CÓPIA DA DECLARAÇÃO DE BENS DOS SÓCIOS DA EMPRESA EXECUTADA “ NÂO PROVMENTO AO RECURSO “ ALEGADA 
VULNERAÇÃO AOS ARTS. 399 DO CPC, 198 DO CTN E 40 DALEIN. 6.830/80 " RECURSO NÄO CONHECIDO.

A requisição judicial, em matéria deste jaez, apenas se justifica desde que haja intransponivel barreira para a obtenção dos dados solicitados por meio da via extrajudicial e, bem assim, a demonstração inequívoca de que a exeqüente envidou esforços para tanto, o Que se não deu na espécie, ou, pelo menos, não foi demonstrado.Falecendo demonstração cabal de Que foram exauridas, sem êxito, as vias administrativas para obtenção de informações referentes aos bens dos sócios, não há demonstração de vulneração aos arts. 399 do CPC e $198 \mathrm{CTN}$, Que conferem ao magistrado a possibilidade de requisitá"las.

Não existindo bens a serem penhorados, e nem demonstrado Qual Quer esforço da exeqüente em obter as informações acerca dos bens de outra forma, correta a suspensăo temporária do processo com base no artigo 40 da Lei n ${ }^{\circ}$ $6.830 / 80$.

A Quebra do sigilo bancário (Lei no $4.595 / 64$ ), perseguida pela Fazenda Pública, é medida excepcional que depende da presença de relevantes motivos. Recurso não conhecido "Precedentes. Decisão unânime.(Segunda Turma, RESP 204329/MG, Rel. Min. Franciulli Netto, DJU, 19/06/2000, p. 131)

O requisito exigível para Que o execüente possa se valer da intermediação do juízo, oficiando às instituições bancárias para Que sejam localizados depósitos bancários suscetíveis de penhora, são os mesmos para Que o BACEN"Iud possa ser acionado, ou sej̧a, Que o exeqüente já tenha esgotado todos os meios à sua disposição, sem sucesso, para a localização de bens do devedor.

No caso em tela, o INSS esclarece as diligências e providências efetuadas na tentativa de localização de bens do executado (cartório de imóveis), tendo até mesmo sido deferida a Quebra de sigilo fiscal. Contudo, as declaraçóes de rendimentos do executado nâo apresentavam bens sujeitos à constrição judicial, conforme informa o agravante.

Assim, verifica"se que o exeqüente esgotou as diligências na busca de bens penhoráveis.

Outrossim, cumpre ressaltar que o deferimento da utilização do Convênio BACENIUD não importa Quebra de sigilo bancário, uma vez que as informações requeridas cingem"se à existência ou não de contas bancárias em nome do devedor e eventual saldo disponível, não se tendo acesso à movimentação financeira do executado. (...)"

Predomina, pois, o entendimento de Que a adoção do BACEN JUD é medida excepcional, estando condicionada à prova inequívoca pelo exeqüente de ter esgotado os meios extrajudiciais de localização de bens aptos à penhora, embora ainda presente a divergência no que diz respeito a se o sistema implica ou não em violação ao sigilo bancário. 
É na Justiça do Trabalho, todavia, Que o sistema BACEN JUD tem sido amplamente utilizado para efetuar a penhora on line através do bloqueio de contas bancárias de empregadores; a fim de satisfazer o crédito dos reclamantes-empregados. No Tribunal Regional do Trabalho da $4^{a}$ Região, os precedentes são inúmeros, destacando-se os seguintes:

AGRAVO DE PETIÇÃO. EXPEDIÇÃO DE OFÍCIO AO BANCO CENTRAL. EXECUÇÄO. SISTEMA BACEN JUD. OC. TST e o Banco Central do Brasil celebraram Convênio de Cooperação Técnico-Institucional, subscrito por este Regional em 05.03.02, possibilitando, aos órgãos judiciários, o acesso via internet ao sistema BACEN JUD, bem como a expedição de oficios eletrônicos às instituiçōes financeiras com a finaliłdade de agilizar as execuções trabalhistas. Desta feita, é parcial o provimento do apelo para assegurar ao exeqüente a obtenção das informações cabíveis junto ao Banco Central, por meio do Sistema BACEN )UD. ((TRT4åR, processo no 00339.305/99-1, Rel. Juíza Tânia Maciel, DI 26/05/2003)

No voto, colhem-se os seguintes argumentos:

(...) Como visto, o autor busca a execução dos créditos trabalhistas que the foram deferidos na sentença transitada em julgado de fls. 47-9, de natureza alimentar, não obtendo êxito no objetivo de pôr termo à execução, Que se arrasta desde o ano de 2000, mostrando-se pertinente a postulação do agravante.

Por outro lado, o C. TST e o Banco Central do Brasil celebraram Convênio de Cooperação Técnico-Institucional possibilitando, aos órgãos judiciários, a utilização de meios técnicos de informatização ágeis e úteis à prestação jurisdicional. Por meio deste, o Banco Central do Brasil permite ao Tribunal Superior do Trabalho, bem como aos Tribunais Regionais do Trabalho que venham a ele aderir, o acesso via internet ao Sistema de Solicitações do Poder Judiciário ao Banco Central do Brasil. Segundo o disposto no parágrafo único da cláusula 1": "Por intermédio do sistema BACEN /UD, o TST e os Tribunais signatários de Termo de Adesão, poderão, dentro de suas áreas de competência, encaminhar às instituiçóes financeiras e demais instituiçôes autorizadas a funcionar pelo BACEN oficios eletrônicos contendo solicitaçöes de informaçöes sobre a existência de contas correntes e aplicaçöes financeiras, determinações de bloqueio e desbloqueio de contas envolvendo pessoas fisicas e jurídicas clientes do Sistema Financeiro Nacional, bem como outras solicitaçôes Que vierem a ser definidas pelas partes". Em 05.03.02, a Presidência deste Regional firmou o Termo de Adesão ao referido Convênio. Assim é que possibilitado o aceso, via internet, ao sistema BACEN JUD, bem como a expedição de ofícios eletrônicos às instituições financeiras com a finalidade de agilizar as execuções trabalhistas.

Outrossim, cumpre ressaltar Que as informações requeridas pelo agravante respeitam à averiguação sobre a eventual existência de contas bancárias em 
nome da executada, e não acerca da movimentação financeira nelas havida, a Qual permanece sigilosa. E mais, não é por demasia registrar Que o agravante não teria acesso às informações solicitadas sem a intervenção do Júzo.

Diante das razöes acima, é parcial o provimento do apelo para assegurar ao exeoüente a obtenção das informações cabíveis junto ao Banco Central, por meio do Sistema BACEN JUD." (TRT4ªR, processo $\pi^{\circ} 00339.305 / 99-1$, Rel. Juíza Tânia Maciel, D| 26/05/2003).

Outro julgado no mesmo sentido:

DA PENHORA SOBRE VALORES EM CONTA BANCÁRIA DA EXECUTADA. Hipótese em Que não se tem a execução como mais gravosa, Quando o Juiz determina o bloqueio de ativos financeiros da executada, mediante o convênio BACEN JUD, junto à Caixa Econômica Federal, com a liberação dos demais bloqueios após ter sido atingido o total do valor da execução. Execução definitiva na Qual a exeqüente não concorda com os bens indicados pela executada. Ausência de abusividade ou llegalidade no ato da autoridade apontada como coatora, Quando faz observar a ordem preferencial do artigo $1 /$ da Lei $6.830 / 80$. Denega-se a segurança. (TRT4aR, MS $n^{\circ}$ 0!640-2004-000-04-00-7, Rel. Juíza Ana Luíza Heineck Kruse, D| 2 I/ 10/2004)

Transcreve-se trecho do voto, bastante oportuna:

Na espécie, a penhora do crédito encontra respaldo na ordem preferencial do artigo $\|$ da Lei $6.830 / 80$. Por oportuno, convém salientar que o sistema BACENJUD é disponibilizado pelo Banco Central do Brasil, em seu site, Que realiza a remessa eletrônica das ordens judiciais às instituiçóes financeiras automaticamente pelo sistema SISBACEN (sistema eletrônico de comunicação entre o BACEN e as instituições bancárias). Neste sentido, o Provimento0 I/2003 da Corregedoria da Justiça do Trabalho, referente à utilização do sistema BACENIUD em se tratando de execução definitiva. Demais, o princípio da menor onerosidade da execução previsto no artigo 620 do CPC não restou afrontado, máxime euando dependente da observância de Que a execução é realizada sempre no interesse do credor (artigo 612 do $\mathrm{CPC}$ ), detentor este de um crédito superprivilegiado. Assim, a Questão da nomeação de bens deve ser analisada conjuntamente com o artigo 612 do CPC, sobrepondo-se ao artigo 620 do mesmo diploma legal, Que deve ser analisado restritivamente em razão dos princípios tutelares trabalhistas. $\mathrm{Na}$ espécie, trata-se de execução definitiva, não tendo a exęüente concordado com a nomeação de bens (fls. 49/50). Logo, não se tem a execução como mais gravosa, Quando determinada a penhora de acordo com a ordem preferencial do artigo 11 da Lei $6.830 / 80$, norma diretamente aplicável ao processo trabalhista (artigo $889 \mathrm{da}$ CLT). 
Aplica-se, ainda, no caso concreto, a Orientação Jurisprudencial no 60 da SDI-2 do TST: "Não fere direito líquido e certo da impetrante o ato judicial Que determina a penhora em dinheiro de banco, em execução definitiva, para garantir crédito exeqüendo, uma vez Que obedece à gradação prevista no art. 655 do CPC. (..)"

Julgado bastante recente trilha o mesmo caminho, com arrimo no Provimento $01 /$ 2003, da Corregedoria-Geral da Justiça do Trabalho, publicado no DI de 01/07/2003, encoraja os magistrados trabalhistas a adotarem prioritariamente o sistema BACEN JUD ${ }^{33}$ :

PENHORA BACEN-JUD. O Provimento no 0l/2003 da Corregedoria Geral da Justiça do Trabalho dispõe, no seu art. $1^{\circ}$, Que se tratando de execução definitiva, o sistema Bacen-Jud deve ser utilizado com prioridade sobre outras modalidades de constrição judicial. Agravo de petição provido. (TRT4aR, AP nº 00208-2000-271-04-00-9, rel. Juíza Maria Helena Mallmann, D| 06/ 2/2004)

Este é o Quadro jurisprudencial acerca da matéria aqui estudada até o momento. Aguarda-se, portanto, a manifestação conclusiva da mais alta Corte do país, o Supremo Tribunal Federal, cujo pronunciamento na ADIN no 309 l-4/DF definirá a Questão de forma definitiva.

\section{CONCLUSÃO}

A intimidade e a vida privada dos contribuintes, aí incluindo-se o sigilo bancário, estão protegidas pela Constituição Federal de 1988, no rol de direitos e garantias fundamentais, mas podem ser relativizadas Quando presente legítimo interesse público.

A penhora on line, instituída pelo sistema BACEN IUD, não provocou ałteração na legislação processual ou material, tratando-se tão-somente de mudança procedimental na efetivação da constrição patrimonial através de meio eletrônico. Trata-se de instrumento Que garante segurança, agilidade e efetividade às decisões emanadas do Poder Judiciário, atendendo aos princípios da economicidade e da máxima eficiência.

Embora não tenha caráter absoluto, o direito ao sigilo bancário está devidamente resguardado através do sistema BACEN IUD, uma vez que a penhora on line é operacionalizada pelo próprio juiz, não disponibilizando ao Fisco Quaisquer informações sobre saldos e aplicaçôes financeiras, respeitando-se o princípio da reserva de jurisdiçâo e do devido processo legal. Há absoluta preservação do núcleo essencial do direito fundamental, Que é a não-divulgação dos dados financeiros do devedor.

${ }^{33}$ Segundo dispõe o art. $1^{\circ}$ do aludido provimento: "Art. $1^{\circ}$ - Tratando-se de execução definitiva, o sistema Bacen Jud deve ser utitizado com prioridade sobre outras modalidades de constrição judicial." 
Eventuais problemas operacionais detectados no sistema, os Quais poderão ser corrigidos por seu gestor, não devem inviabilizar a adoção da penhora on line, Que há de ser vista como inovação louvável e irremediável da modernidade, Que atende não só ao interesse do Estado-credor, mas de todos aqueles possuidores de títulos executivos que têm frustrada a possibilidade de êxito na execução, como medida hábil à satisfação de seus créditos, vislumbrado o interesse da justiça e da efetividade da jurisdição.

Cumpre sinalar Que o sistema está sendo adotado dentro dos parâmetros fixados pelos signatários do convênio e no estrito respeito aos preceitos constantes da Constituiçá̃o Federal e da legislação pertinente, conforme vimos através dos precedentes jurisprudenciais.

Por todo o exposto, verificando-se que não se trata de instrumento revelador da privacidade consagrada na Constituição Federal de 1988, conclui-se que não há quebra do sigilo bancário quando da efetivação da penhora on line através do sistema BACEN IUD.

\section{REFERÊNCIAS BIBLIOGRÁFICAS}

ALVARES, Manoel et al. Execução Fiscal, Doutrina e lurisprudência. Coordenação Vladimir Passos de Freitas. São Paulo: Saraiva, 1998.

ASSIS, Araken de. Manual do Processo de Execução. $5^{a}$ ediçăo. São Paulo: Editora Revistas dos Tribunais, 1998.

BALTAZAR JÚNIOR, José Paulo. Sigilo bancário e privacidade. Porto Alegre: Livraria do Advogado Editora, 2005

BAPTISTA DA SILVA, Ovídio. Curso de Processo Civil. Vol. Il. Porto Alegre: Sergio Antonio Fabris Editor, 1990

BARBEITAS, André Terrigno. O sigilo bancário e o resguardo da intimidade e da vida privada. Boletim Científico. Escola Superior do Ministério Público da União. Ano ll n n 6 - janeiro/ março de 2003.

FERRAZ JÚNIOR, Tércio Sampaio. Sigilo bancário. Revista Fórum de Direito Tributário v. 0 I no I, fls. 64-80. Belo Horizonte, Editora Fórum, jan-fev.2003.

FOLMANN, Melissa. Interpretação constitucional principiológica \& sigilo bancário. la edição. $3^{a}$ tiragem. Curitiba: Juruá Editora, 2004.

GÓMES, Lineu Miguel. Penhora on line . jus Navigandi, Teresina, a. 8, n. 237, 1 mar. 2004. Disponivel em: <http://wwwl .jus.com.br/doutrina/texto.asp?id=486l >. Acesso em: $22 \mathrm{fev}$. 2005.

MACHADO, Hugo de Brito. A quebra do sigilo bancário. Repertório IOB de Jurisprudência $n^{\circ}$ 09/2001. Caderno I.

MORAES, Alexandre de. Direito Constitucional. 15a ed. São Paulo: Atlas, 2004. 
PAULSEN, Leandro. Direito Tributário. Constituição e Código Tributário à Luz da Doutrina e da Jurisprudência. $7^{\text {a }}$ ediçẫo. Porto Alegre: Livraria do Advogado, 2005.

SARAIVA FILHO, Oswaldo Othon de Pontes. O acesso direto aos dados bancários por parte do Fisco: a Transferência do sigilo bancário para o sigilo fiscal. Revista Fórum de Direito Tríbutário no I I. Belo Horizonte: Editora Fórum, 2004.

TAGLIAFERRO, Kleber Auguto. A Constituição Federal e a Lei do Sigilo Bancário: Tensăo entre Princípios. Revista Dialética de Direito Tributário, No 66. São Paulo: Dialética, 2001

TEIXEIRA, Eduardo Didonet; HAEBERLIN, Martin. A proteção da Privacidade. Aplicação na Quebra do sigilo bancário e fiscal. Porto Alegre: Sergio Antônio Fabris Ed, 2005.

TOURINHO, Lifian Oliveira da Costa. A Quebra do sigilo bancário trazida pela Lei Complementar 105/200 I à luz da Constituição de 1988. Revista da Associação dos fúizes Federais do Brasil, nº 75/76, Editora Impetus, 2004.

REVISTA DO TRIBUNAL REGIONAL FEDERAL DA $4^{a}$ REGIÃO no 29, Porto Alegre, 1998 , p. 357-371. 